University of Nebraska - Lincoln

DigitalCommons@University of Nebraska - Lincoln

\title{
Aquifer-scale controls on the distribution of nitrate and ammonium in ground water near La Pine, Oregon, USA
}

Stephen R. Hinkle

U.S. Geological Survey, srhinkle@usgs.gov

J. K. Böhlke

U.S. Geological Survey

John H. Duff

U.S. Geological Survey, jhduff@usgs.gov

David S. Morgan

U.S. Geological Survey

Rodney J. Weick

Oregon Department of Enviromental Quality

Follow this and additional works at: https://digitalcommons.unl.edu/usgsstaffpub

Part of the Earth Sciences Commons

Hinkle, Stephen R.; Böhlke, J. K.; Duff, John H.; Morgan, David S.; and Weick, Rodney J., "Aquifer-scale controls on the distribution of nitrate and ammonium in ground water near La Pine, Oregon, USA" (2007). USGS Staff -- Published Research. 422.

https://digitalcommons.unl.edu/usgsstaffpub/422

This Article is brought to you for free and open access by the US Geological Survey at DigitalCommons@University of Nebraska - Lincoln. It has been accepted for inclusion in USGS Staff -- Published Research by an authorized administrator of DigitalCommons@University of Nebraska - Lincoln. 


\title{
Aquifer-scale controls on the distribution of nitrate and ammonium in ground water near La Pine, Oregon, USA is
}

\author{
Stephen R. Hinkle ${ }^{a, k}$, J.K. Böhlke ${ }^{b}$, John H. Duff ${ }^{c}$, \\ David S. Morgan ${ }^{a}$, Rodney J. Weick ${ }^{\mathrm{d}}$
}

a US Geological Survey, 10615 SE Cherry Blossom Drive, Portland, OR 97216, USA

b US Geological Survey, 431 National Center, 12201 Sunrise Valley Drive, Reston, VA 20192, USA

c US Geological Survey, 439 McKelvey Building, 345 Middlefield Road, Menlo Park, CA 94025, USA

' Oregon Department of Environmental Quality, 811 SW Sixth Avenue, Portland, OR 97204, USA

Received 21 December 2005; received in revised form 15 September 2006; accepted 19 September 2006

\author{
KEYWORDS \\ Septic systems; \\ Ground water; \\ Denitrification; \\ Geochemistry; \\ Ammonium ion
}

Summary Geochemical and isotopic tools were applied at aquifer, transect, and subtransect scales to provide a framework for understanding sources, transport, and fate of dissolved inorganic $\mathrm{N}$ in a sandy aquifer near $\mathrm{La}$ Pine, Oregon. $\mathrm{NO}_{3}$ is a common contaminant in shallow ground water in this area, whereas high concentrations of $\mathrm{NH}_{4}-$ $\mathrm{N}$ (up to $39 \mathrm{mg} / \mathrm{L}$ ) are present in deep ground water. $\mathrm{N}$ concentrations, $\mathrm{N} / \mathrm{Cl}$ ratios, tracer-based apparent ground-water ages, $\mathrm{N}$ isotope data, and hydraulic gradients indicate that septic tank effluent is the primary source of $\mathrm{NO}_{3} . \mathrm{N}$ isotope data, $\mathrm{N} / \mathrm{Cl}$ and $\mathrm{N} / \mathrm{C}$ relations, ${ }^{3} \mathrm{H}$ data, and hydraulic considerations point to a natural, sedimentary organic matter source for the high concentrations of $\mathrm{NH}_{4}$, and are inconsistent with an origin as septic tank $\mathrm{N}$. Low recharge rates and flow velocities have largely restricted anthropogenic $\mathrm{NO}_{3}$ to isolated plumes within several meters of the water table. A variety of geochemical and isotopic data indicate that denitrification also affects $\mathrm{NO}_{3}$ gradients in the aquifer. Ground water in the La Pine aquifer evolves from oxic to increasingly reduced conditions. Suboxic conditions are achieved after about 15-30 y of transport below the water table. $\mathrm{NO}_{3}$ is

\footnotetext{
This article is a US Government work and is in the public domain in the USA. Any use of trade, product, or firm names is for descriptive purposes only and does not imply endorsement by the US Government.

* Corresponding author. Fax: +1 5032513470.

E-mail address: srhinkle@usgs.gov (S.R. Hinkle).
}

0022-1694/\$ - see front matter (c) 2006 Elsevier B.V. All rights reserved. doi:10.1016/j.jhydrol.2006.09.013 
denitrified near the oxic/suboxic boundary. Denitrification in the La Pine aquifer is characterized well at the aquifer scale with a redox boundary approach that inherently captures spatial variability in the distribution of electron donors.

(c) 2006 Elsevier B.V. All rights reserved.

\section{Introduction}

Nitrate $\left(\mathrm{NO}_{3}\right)$ is the most common contaminant in ground water (Spalding and Exner, 1993). Identification of sources of $\mathrm{NO}_{3}$, as well as other nitrogen $(\mathrm{N})$ species, has received a tremendous amount of attention, due in part to health concerns regarding $\mathrm{NO}_{3}$ ingestion (World Health Organization, 1996) and to potential ecosystem effects of $N$ loading (Howarth and Marino, 2006). For example, the history and fate of $\mathrm{NO}_{3}$ contamination have been carefully evaluated in multidisciplinary local transect studies in areas with agricultural sources (e.g. Böhlke and Denver, 1995; Tesoriero et al., 2000; Böhlke et al., 2002; Puckett et al., 2002) and septic tank sources (e.g. Robertson and Cherry, 1992; Wilhelm et al., 1996; Aravena and Robertson, 1998). However, resolution of $\mathrm{N}$ sources can be difficult in larger regional studies because of co-occurrence of multiple anthropogenic $\mathrm{N}$ sources and uncertainty in $\mathrm{N}$ transformation pathways. Furthermore, natural $\mathrm{N}$ may be an important but overlooked $\mathrm{N}$ source in some aquifers. Thus, identification of natural and anthropogenic $\mathrm{N}$ sources, as well as characterization of $\mathrm{N}$ geochemistry, remain challenging, particularly in aquifer-scale assessments.

In this paper, we present results of a multiscale study of $\mathrm{N}$ occurrence, loading, transport and fate for a sandy aquifer in Oregon, USA, in which the only significant anthropogenic $\mathrm{N}$ source (other than atmospheric loading) was septic tank effluent. The near absence of other anthropogenic $\mathrm{N}$ sources provided an opportunity to characterize the impact and point-source nature of septic tank $\mathrm{N}$ discharge to the aquifer. An important natural $\mathrm{N}$ source also was clearly identified and several approaches were used to distinguish between anthropogenic and natural $\mathrm{N}$ sources. Multiple lines of evidence point to a denitrification pathway for $\mathrm{NO}_{3}$ removal from ground water, and a redox boundary approach is proposed for conceptualizing aquifer-scale $\mathrm{NO}_{3}$ fate.

\section{Study area and background}

Rapid rural-residential development on lots as small as onehalf acre (0.2 ha) has occurred in the vicinity of La Pine, Oregon, USA (Fig. 1) since the 1960s. A shallow, sandy aquifer serves as both source of drinking water and receptor of septic tank effluent for most residents. Most houses in this semiarid environment are surrounded by semidesert landscaping, and agricultural activities are almost nonexistent (Oregon Department of Environmental Quality, 1994; Hinkle et al., 2005). Fertilizer use is minimal, and septic tank effluent is the only important anthropogenic source of $\mathrm{N}$ to study area ground water (Century West Engineering Corporation, 1982). High concentrations of $\mathrm{NO}_{3}-\mathrm{N}(>10 \mathrm{mg} / \mathrm{L})$ became widespread in ground water beneath the town of La Pine by the early 1980s (Century West Engineering Corporation, 1982). Sewering of the core urban area of La Pine has re- duced septic tank effluent loading there. However, most of the surrounding area is unlikely to support centralized sewer or water supply services in the foreseeable future. As of 1999, 5185 rural platted lots had been developed. Another 5010 developable lots remained in 1999. Hence, County and State resource managers are in need of an understanding of $\mathrm{NO}_{3}$ source, transport and fate in the $\mathrm{La}$ Pine area. The work described in this paper arose in response to these needs, but the results have wider applicability.

The La Pine study area lies in Oregon's upper Deschutes Basin (Fig. 1). The area is underlain by as much as $300 \mathrm{~m}$ of Quaternary alluvial and lacustrine deposits in a structural basin of Quaternary and Tertiary basalt, andesite, vent deposits, and pyroclastic rocks (Lite and Gannett, 2002). Sand is common in the uppermost $37 \mathrm{~m}$ of the aquifer. Deeper sediment is dominantly fine grained, and includes extensive lacustrine deposits. Most ground-water use, and hence our emphasis, is focused in the uppermost $37 \mathrm{~m}$ of the aquifer.

Rain and snowmelt are the primary sources of recharge in the study area. Precipitation ranges from 40 to $50 \mathrm{~cm} / \mathrm{y}$ over most of the area (Taylor, 1993), falling primarily from November through March. Regional ground-water fluxes from higher-elevation areas enter the study area from the west, and to lesser extents the south and east (Gannett et al., 2001). Ground water discharges to the Deschutes and Little Deschutes Rivers. The water table generally lies within $6 \mathrm{~m}$ of land surface, facilitating additional ground water loss via evapotranspiration.

\section{Study design and methods}

\section{Well networks and other data}

Chemical analyses of ground water from a network of 193 existing (primarily domestic) wells, sampled by Oregon Department of Environmental Quality (ODEQ) in June, 2000 , provided an aquifer-scale $\left(640 \mathrm{~km}^{2}\right.$ area of variable thickness) perspective of the distribution of dissolved oxygen $\left(\mathrm{O}_{2}\right)$ (188 sites), $\mathrm{NO}_{3}$ (192 sites), ammonium $\left(\mathrm{NH}_{4}\right)$ (192 sites), and chloride ( $\mathrm{Cl})$ (191 sites). This network is referred to as the ODEQ synoptic network. (The raw data are provided as Supplemental data: supplemental_data_1.xls.)

Ground water from a group of 11 existing wells with elevated $\mathrm{NH}_{4}-\mathrm{N}(>1 \mathrm{mg} / \mathrm{L})$ was sampled by the US Geological Survey (USGS). These wells were primarily a subset of the ODEQ synoptic network. Samples were analyzed for field parameters; nutrients ( $\mathrm{N}$ and phosphorus [P] species); nonpurgable dissolved organic carbon (DOC); common ions; dissolved nitrogen $\left(\mathrm{N}_{2}\right)$, argon $(\mathrm{Ar})$, and methane $\left(\mathrm{CH}_{4}\right) ; \delta^{15} \mathrm{~N}$ in $\mathrm{NH}_{4}$; and tritium $\left({ }^{3} \mathrm{H}\right)$. These data were used to determine the origin of elevated $\mathrm{NH}_{4}$ concentrations in ground water. This network is referred to as the "elevated- $\mathrm{NH}_{4}$ network". 


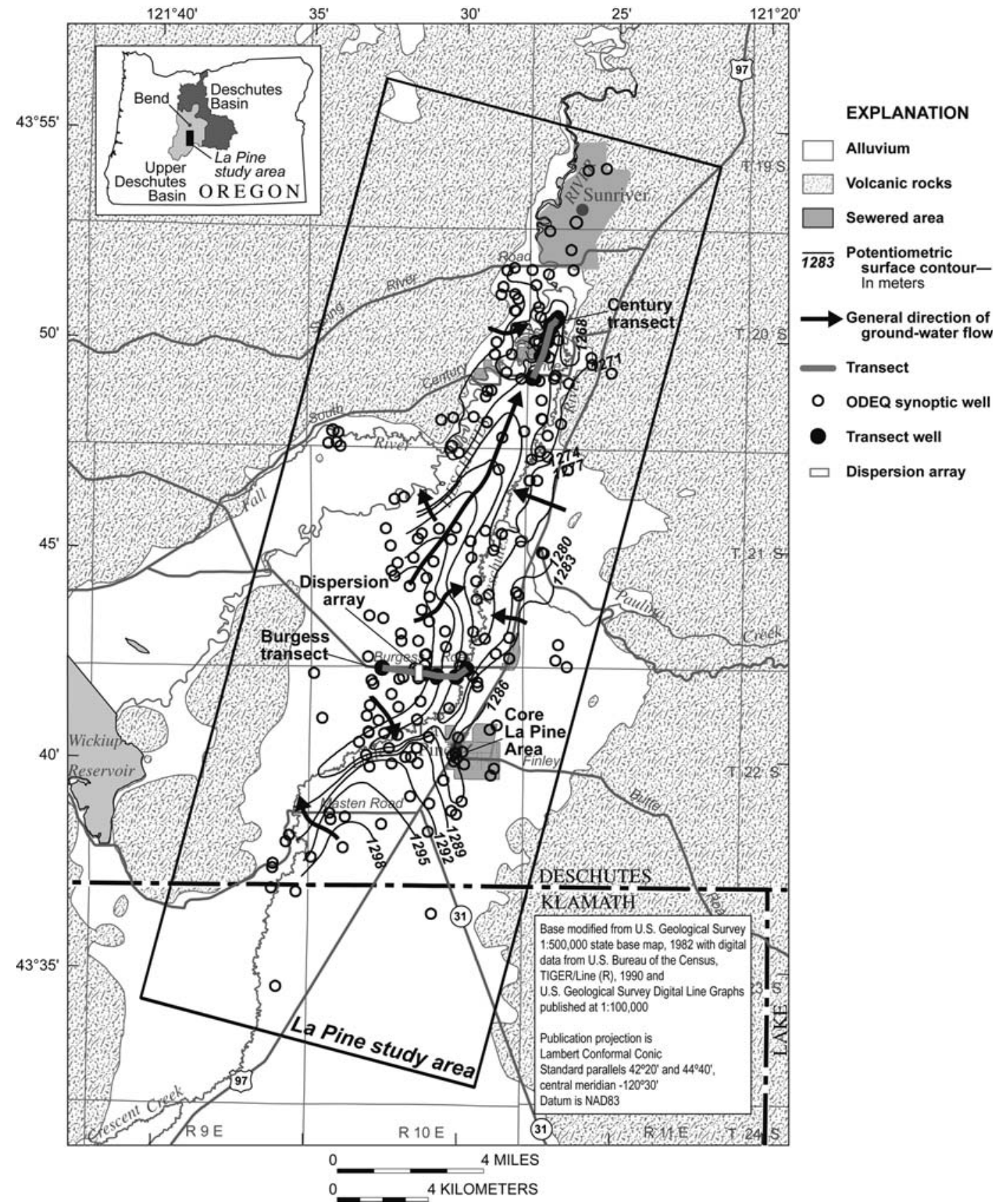

Figure 1 La Pine study area.

The USGS installed monitoring wells along two groundwater flowpaths (Burgess and Century transects, Fig. 1) and sampled the ground water for field parameters; nutrients; DOC; common ions; dissolved $\mathrm{N}_{2}, \mathrm{Ar}, \mathrm{CH}_{4}$, and, at selected sites, neon (Ne); $\delta^{15} \mathrm{~N}$ in $\mathrm{NO}_{3}, \mathrm{NH}_{4}$, and/or $\mathrm{N}_{2}$ (selected sites); and age-dating tracers (chlorofluorocarbons [CFCs] or ${ }^{3} \mathrm{H} ;{ }^{3} \mathrm{H}$ with ${ }^{3} \mathrm{He}$ and ${ }^{4} \mathrm{He}$ for ${ }^{3} \mathrm{H} /{ }^{3} \mathrm{He}$ age dating at selected sites). These data provided an understanding of the movement and geochemical evolution of ground water at the sub-aquifer scale. One to four wells were installed at each of six locations along transects, with a total of 17 wells along the Burgess transect and eight along the Century transect. Each site (containing one to four wells) was assigned a name, beginning with transect name ("Burgess" or "Century"), followed by a sequential number corre- sponding to location along the transect, with "1" being furthest upgradient and "6" furthest downgradient. Most sites contained nests of two to four wells; names for these wells included a decimal followed by a digit corresponding to position within the nest ("1" for shallowest).

Transect wells were drilled with a hollow stem auger. Drilling fluids were not used, except at Burgess 2.4, where $68 \mathrm{~L}$ of tap water was added to prevent sand surging. Much of this water was immediately removed after placement of casing, and along with subsequent pumping, a total of $727 \mathrm{~L}$ was removed - a volume sufficient to ensure that contamination was unlikely. Wells were completed with $5.1-\mathrm{cm}$ diameter steam-cleaned PVC casing and 0.59-m-length screens. Native sediment usually caved around screens; otherwise, washed quartz sand was added. Well bores were 
sealed with bentonite. Well development was done by surging and pumping.

ODEQ installed 33 temporary wells in an array near the Burgess transect (Fig. 1). This dense array, occupying a vertical plane $730 \mathrm{~m}$ long and $6.4 \mathrm{~m}$ deep, was oriented perpendicular to the Burgess transect at nest 2 . These wells were installed by direct push of a 0.61 -m-long stainless steel screen. Development of these wells was done with a peristaltic pump. These wells were sampled by ODEQ for $\mathrm{NO}_{3}$, $\mathrm{NH}_{4}$, and $\mathrm{Cl}$ (32 wells) and $\mathrm{O}_{2}$ (33 wells) to provide information on solute dispersion normal to the direction of flow. This network of wells is referred to as the dispersion array. (The raw data are provided as Supplemental data: supplemental_data_2.xls.)

ODEQ used direct-push drilling to install one well near the center of each of three plumes of septic tank effluent. Plumes were identified by drilling and sampling from multiple exploratory wells on the downgradient side of septic tank drainfields; plume centers generally were characterized by $\mathrm{NO}_{3}-\mathrm{N}>10 \mathrm{mg} / \mathrm{L}$. Wells were developed by pumping with a peristaltic pump. The USGS sampled these wells for nutrients, $\delta^{15} \mathrm{~N}-\mathrm{NO}_{3}$, and $\mathrm{Cl}$. Water from one of these wells, DEQ1227, also was analyzed for DOC, common ions, and field parameters. These data supplemented ODEQ study area septic tank effluent data.

Atmospheric precipitation data were used to characterize potential background chemical fluxes. Precipitationweighted mean $\mathrm{N}$ and $\mathrm{Cl}$ concentrations for calendar year 1999 (National Atmospheric Deposition Program, no date) for the Silver Lake Ranger Station (70 km SE of La Pine) were assumed typical of study area precipitation.

\section{Sample collection and analysis}

\section{ODEQ samples}

ODEQ samples (synoptic network and dispersion array) were collected following stabilization of field parameters. $\mathrm{O}_{2}$ was measured electrochemically in situ, or by iodometric titration on-site. Samples for $\mathrm{Cl}$ were filtered on-site through 0.45- $\mu \mathrm{m}$ nominal-pore-size capsule filters. Samples for $\mathrm{NO}_{3}$ and $\mathrm{NH}_{4}$ from the ODEQ synoptic network were filtered in the laboratory $(0.45-\mu \mathrm{m}$ plate filters), whereas those from the dispersion array were filtered on-site through $0.45-\mu \mathrm{m}$ capsule filters. Samples for $\mathrm{NO}_{3}$ and $\mathrm{NH}_{4}$ were preserved on-site with sulfuric acid to $\mathrm{pH}<2$. Analytical techniques are described by Clesceri et al. (1998). ODEQ analytical techniques were evaluated by the USGS interlaboratory analytical evaluation program. This blind sample program uses natural-matrix standard reference materials. Results are published semiannually (e.g. Farrar and Copen, 2000; Connor et al., 2001).

\section{USGS samples}

USGS sample collection and processing protocols are briefly described below. Greater detail is provided in US Geological Survey (1999).

Samples were generally collected after both purging of at least three bore volumes and stabilization of field parameters. $\mathrm{O}_{2}, \mathrm{pH}$, temperature, and specific conductance were measured electrochemically in situ. Alkalinity was measured on-site and in duplicate by titration.
Wells in the elevated- $\mathrm{NH}_{4}$ network were primarily domestic wells, and had submersible pumps. Where possible, wells were sampled near the well head and upgradient from pressure tanks. If access upgradient from pressure tanks was unavailable, dissolved gases were not collected. Burgess and Century transect wells were sampled with a submersible pump; wetted pump parts were stainless steel and fluorocarbon polymer. Two types of tubing (copper and fluorocarbon polymer) were attached to the pump with a stainless steel union. CFC samples were collected from copper tubing. Other samples were collected from fluorocarbon polymer tubing. Monitoring wells in septic tank effluent plumes were sampled with a peristaltic pump.

Samples for nutrients, common ions, alkalinity, $\delta^{15} \mathrm{~N}-$ $\mathrm{NO}_{3}$, and $\delta^{15} \mathrm{~N}-\mathrm{NH}_{4}$ were filtered through in-line $0.45-\mu \mathrm{m}$ nominal-pore-size one-time-use capsule filters. Capsule filters were flushed with $1 \mathrm{~L}$ of deionized water and then flushed with sample water to remove deionized water prior to use. Cation samples (except $\mathrm{NH}_{4}$ ) were preserved with ultrapure nitric acid $(\mathrm{pH}<2)$. Samples for DOC were filtered through $0.45-\mu \mathrm{m}$ nominal-pore-size silver plate filters. Samples for $\mathrm{N}_{2}$, Ar, and $\mathrm{CH}_{4}$ concentrations and for $\delta^{15} \mathrm{~N}-\mathrm{N}_{2}$ were collected in a gas-free environment and preserved with potassium hydroxide. CFC samples were collected in flame-sealed borosilicate glass ampules under an atmosphere of purified $\mathrm{N}_{2}$ following protocols of Busenberg and Plummer (1992). Samples for analysis of $\mathrm{Ne},{ }^{4} \mathrm{He}$, and $\delta^{3} \mathrm{He}$ were collected in-line in copper tubes that were crimped while under back-pressure. Samples for analysis of ${ }^{3} \mathrm{H}$ were collected in glass bottles or copper tubes.

Nutrients, common ions, and DOC were analyzed at the USGS National Water Quality Laboratory in Denver, Colorado (Fishman and Friedman, 1989; Patton and Truitt, 1992; Brenton and Arnett, 1993; Fishman, 1993; Patton and Truitt, 2000). Dissolved $\mathrm{N}_{2}, \mathrm{Ar}$, and $\mathrm{CH}_{4}$ were measured at the USGS Dissolved Gas Laboratory in Reston, Virginia, by gas chromatography (Busenberg et al., 1998). Isotopes of $\mathrm{N}$ were analyzed by mass spectrometry at the USGS Reston Stable Isotope Laboratory and are reported relative to $\mathrm{N}_{2}$ in air (AIR; Coplen, 1993). Methods of freeze drying, combustion and analysis of $\delta^{15} \mathrm{~N}-\mathrm{NO}_{3}$, and combustion and analysis of $\delta^{15} \mathrm{~N}-\mathrm{N}_{2}$, were those of Böhlke and Denver (1995), with modification of the combustion reagents according to Böhlke et al. (1993). Methods of $\mathrm{NH}_{4}$ extraction from water samples, combustion and analysis were those of Böhlke et al. (2006). Analyses of $\delta^{15} \mathrm{~N}-\mathrm{NO}_{3}$ and $\delta^{15} \mathrm{~N}-\mathrm{NH}_{4}$ were calibrated by analyzing laboratory solutions with known isotopic compositions, and the data were normalized against international reference materials according to Böhlke and Coplen (1995). Analyses of $\delta^{15} \mathrm{~N}-\mathrm{N}_{2}$ were calibrated by analyzing air and air-equilibrated laboratory water samples. Samples for CFCs were analyzed in triplicate at the USGS Reston Chlorofluorocarbon Laboratory by purge-and-trap gas chromatography with an electron-capture detector (Busenberg and Plummer, 1992; Busenberg et al., 1998).

Tritium in ground-water samples from the elevated- $\mathrm{NH}_{4}$ network, from Burgess 6.2, and from Century 1.2 and 6.2 were analyzed at the University of Miami Tritium Laboratory. Analysis was by electrolytic enrichment and gas counting (Östlund et al., 1974).

Analysis of $\mathrm{Ne},{ }^{4} \mathrm{He}$, and $\delta^{3} \mathrm{He}$ was done at Lamont-Doherty Earth Observatory of Columbia University (LDEO). Ne 
was measured in a quadrupole mass spectrometer. Helium-4 and $\delta^{3} \mathrm{He}$ were measured in a dedicated helium isotope mass spectrometer. Tritium for ${ }^{3} \mathrm{H} /{ }^{3} \mathrm{He}$ age dating also was measured at LDEO, using the ${ }^{3} \mathrm{He}$ ingrowth method. Analytical methods used at LDEO are described in Plummer and Mullin $(1997 a, b)$, and references therein.

\section{Reporting and plotting conventions}

Samples analyzed by USGS and ODEQ for $\mathrm{NO}_{3}$ were analyzed for nitrite-plus-nitrate $\left(\mathrm{NO}_{2}+\mathrm{NO}_{3}\right)$. USGS samples analyzed for $\mathrm{NO}_{2}+\mathrm{NO}_{3}$ were also analyzed for $\mathrm{NO}_{2}$, and $\mathrm{NO}_{2}$ concentrations were consistently negligible. We assume that $\mathrm{NO}_{2}$ also was negligible in ODEQ-analyzed samples, and thus refer to $\mathrm{NO}_{2}+\mathrm{NO}_{3}$ as $\mathrm{NO}_{3}$.

For plotting purposes, USGS $\mathrm{NO}_{3}$ and ODEQ $\mathrm{NO}_{3}$ and $\mathrm{Cl}$ concentrations below the minimum reporting level (MRL) were plotted at one-half of the MRL. The USGS and ODEQ $M R L$ for $\mathrm{NO}_{3}-\mathrm{N}$ was $0.005 \mathrm{mg} / \mathrm{L}$, and for ODEQ $\mathrm{Cl}, 0.5 \mathrm{mg} / \mathrm{L}$.

\section{Results and discussion}

\section{Aquifer scale distribution of $\mathrm{NO}_{3}$ and $\mathrm{NH}_{4}$}

An aquifer-scale understanding of $\mathrm{N}$ distribution was provided by the ODEQ synoptic network. Ground-water samples containing $>1 \mathrm{mg} / \mathrm{L} \mathrm{NO}_{3}-\mathrm{N}$ represented $22 \%$ of the sites, although samples from only two sites (1\% of the sites) exceeded the US Environmental Protection Agency (USEPA) Maximum Contaminant Level of $10 \mathrm{mg} / \mathrm{L} \mathrm{NO}-\mathrm{N}$. $\mathrm{NO}_{3}$ currently occurs primarily near the water table. Well construction data were available for $89 \%$ of ODEQ synoptic network wells; of this group, ground water that contained $>1 \mathrm{mg} / \mathrm{L}$ $\mathrm{NO}_{3}-\mathrm{N}$ came from shallow wells in which the tops of the open intervals had median and maximum depths below water table of $3.3 \mathrm{~m}$ and $8.1 \mathrm{~m}$, respectively.

Elevated concentrations of $\mathrm{NH}_{4}-\mathrm{N}(>1 \mathrm{mg} / \mathrm{L})$ were observed in $17 \%$ of the ground-water samples from the ODEQ synoptic network, and concentrations as high as $39 \mathrm{mg} / \mathrm{L}$ $\mathrm{NH}_{4}-\mathrm{N}$ were documented. Well construction data were available for 171 of the 192 sites sampled for $\mathrm{NH}_{4}$. Of these 171 sites, 30 yielded ground water with $>1 \mathrm{mg} / \mathrm{L} \mathrm{NH}_{4}-\mathrm{N}$. The 30 sites with elevated concentrations of $\mathrm{NH}_{4}$ generally were deep or in the near-river environment, and the deeper samples among these tended to contain higher concentrations of $\mathrm{NH}_{4}$ than did the shallower samples. Of the 30 sites with elevated concentrations of $\mathrm{NH}_{4}, 17$ were wells in which the depth of the top of the open interval below the water table was $>37 \mathrm{~m}$ (median $\mathrm{NH}_{4}-\mathrm{N} 8.2 \mathrm{mg} / \mathrm{L}$ ), and of the 13 shallow sites (median $\mathrm{NH}_{4}-\mathrm{N} 3.2 \mathrm{mg} / \mathrm{L}$ ), 10 were located within $600 \mathrm{~m}$ of rivers. Thus, in contrast to the distribution of $\mathrm{NO}_{3}$ concentrations, $\mathrm{NH}_{4}$ concentrations exceeding $1 \mathrm{mg} /$ $\mathrm{L} \mathrm{NH}_{4}-\mathrm{N}$ generally were detected in deep ground water or in shallow ground water near rivers, the latter possibly representing deep ground water moving towards rivers, which serve as drains for regional ground water.

\section{Ground-water age and temporal aspects of $\mathrm{NO}_{3}$ and $\mathrm{NH}_{4}$ occurrence}

Age-dating techniques were used to estimate ground-water travel times along flowpaths. Age-dating information allowed us to determine whether ground water containing elevated concentrations of $\mathrm{NO}_{3}$ and $\mathrm{NH}_{4}$ was of recent origin (thus possibly related to anthropogenic activities), or if the ground water predated anthropogenic influences in the study area (thus implicating natural sources of $\mathrm{NO}_{3}$ or $\mathrm{NH}_{4}$ ). Physical, chemical and isotopic data from transects (Table 1) also helped define the distribution of $\mathrm{NO}_{3}$ and $\mathrm{NH}_{4}$ in the context of space and time.

Estimated recharge temperatures are needed for calculating apparent ground-water ages from CFC or ${ }^{3} \mathrm{H} /{ }^{3} \mathrm{He}$ data. Recharge temperature often is close to the mean annual air temperature (Andrews, 1992) or the mean annual soil temperature at the water table (about $1^{\circ} \mathrm{C}$ greater than the mean annual air temperature; Stute and Schlosser, 2000). The mean annual air temperature in the study area is $7.2^{\circ} \mathrm{C}$ (mean of mean annual air temperatures at the Wickiup Reservoir and Bend climate stations; Fig. 1) (National Climatic Data Center, 2005a,b). However, Ne and Ar concentrations plot along an excess air curve indicating a median recharge temperature of $5.2^{\circ} \mathrm{C}$ (Fig. 2). Most study area recharge enters sediment between late fall and early spring as direct infiltration of precipitation and snowmelt. Much of this recharge occurs in a pulse during spring snowmelt and possibly takes little time to travel through the thin unsaturated zone. The difference between the mean annual air temperature $\left(7.2^{\circ} \mathrm{C}\right.$ ) and the recharge temperature estimated from $\mathrm{Ne}$ and $\mathrm{Ar}$ concentrations $\left(5.2^{\circ} \mathrm{C}\right)$ may reflect recharge primarily during colder months. Thus, a recharge temperature of $5.2^{\circ} \mathrm{C}$ was used in calculations. A $2.0^{\circ} \mathrm{C}$ increase in assumed recharge temperature would result in a median difference of $1 \mathrm{y}$ in the CFC apparent ages calculated below and less than $0.1 \mathrm{y}$ in the ${ }^{3} \mathrm{H} /{ }^{3} \mathrm{He}$ apparent ages.

All transect wells except Burgess 6.2, Century 1.2, and Century 6.2 were sampled for CFC-12, CFC-11, and CFC113. A CFC-based apparent age represents the time of travel for water particles from their points of recharge at the water table to a well (Busenberg and Plummer, 1992; Cook and Solomon, 1997; Plummer and Busenberg, 2000). In general, CFC-12 concentrations provide the most reliable CFC apparent ages because CFC-12 does not tend to sorb and is resistant to microbial degradation until methanogenic conditions become well established, whereas CFC-11 and CFC-113 are more susceptible to microbial degradation and may sorb to organic carbon (Plummer and Busenberg, 2000). Thus, we generally used the median CFC-12 apparent age at most sites. However, samples from three sites (Century 1.1 , Century 4 , and Century 5 ) contained CFC-12 concentrations that were greater than could be accounted for by simple air-water solubility and that were highly variable among sequential samples (Table 2), thus indicating the presence of CFC-12 contamination. In instances where CFC-12 contamination was indicated, CFC-11 and CFC-113 apparent ages were evaluated. If the CFC-11 and CFC-113 apparent ages were similar (within $4 \mathrm{y}$, i.e. Century 1.1 and Century 4), the median of the six CFC-11 and CFC-113 apparent ages was used. On the other hand, if the CFC-12 concentrations indicated the presence of contamination, and the CFC-11 and CFC-113 apparent ages were not similar, the CFC-11 and CFC-113 may have been degraded, and the water was considered undatable by CFCs; this was the case for Century 5. Finally, the highly reducing conditions at Burgess $6.1\left(1.07 \mathrm{mg} / \mathrm{L} \mathrm{CH}_{4}, 12.3 \mathrm{mg} / \mathrm{L}\right.$ iron [Fe], and no 


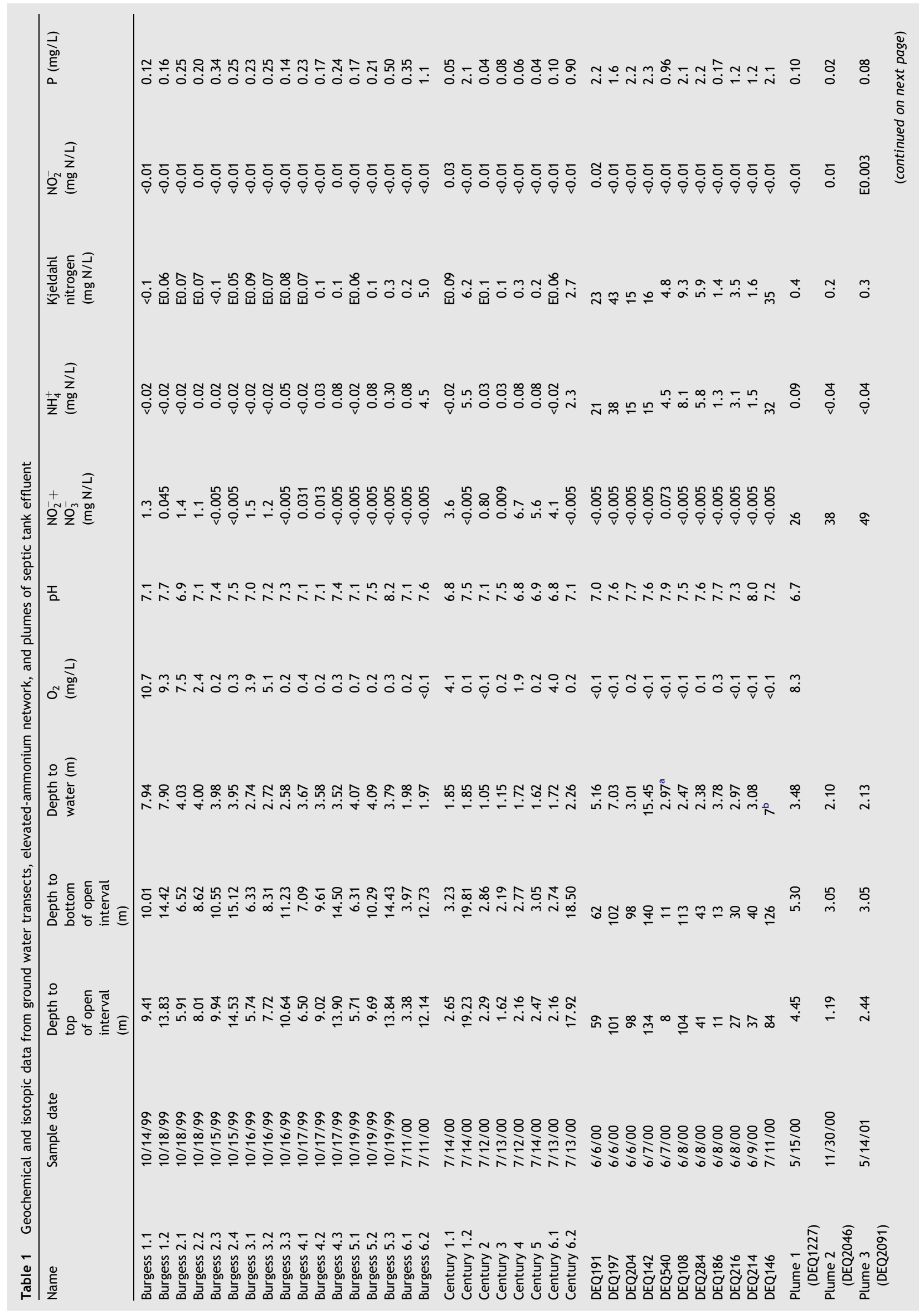




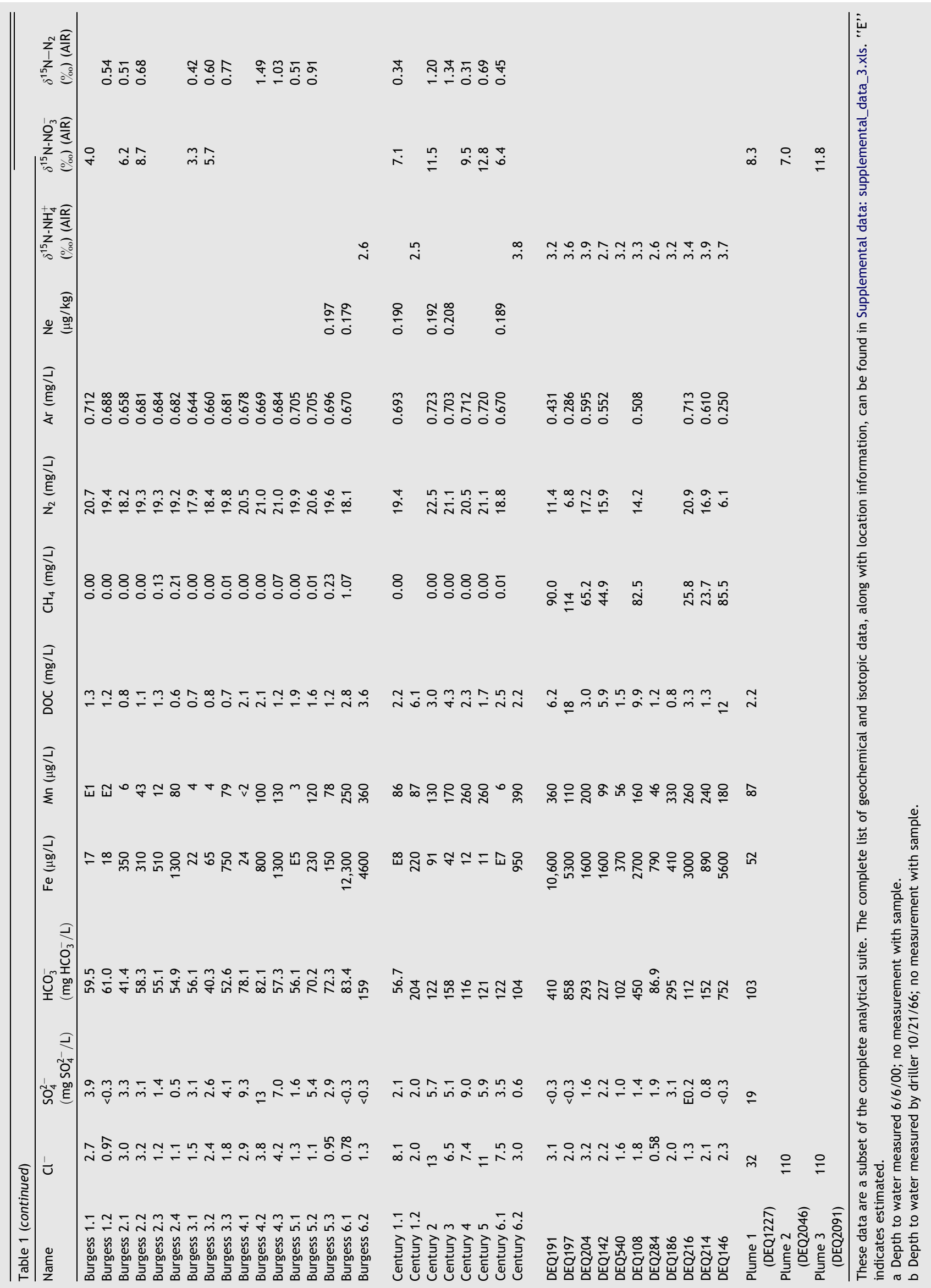




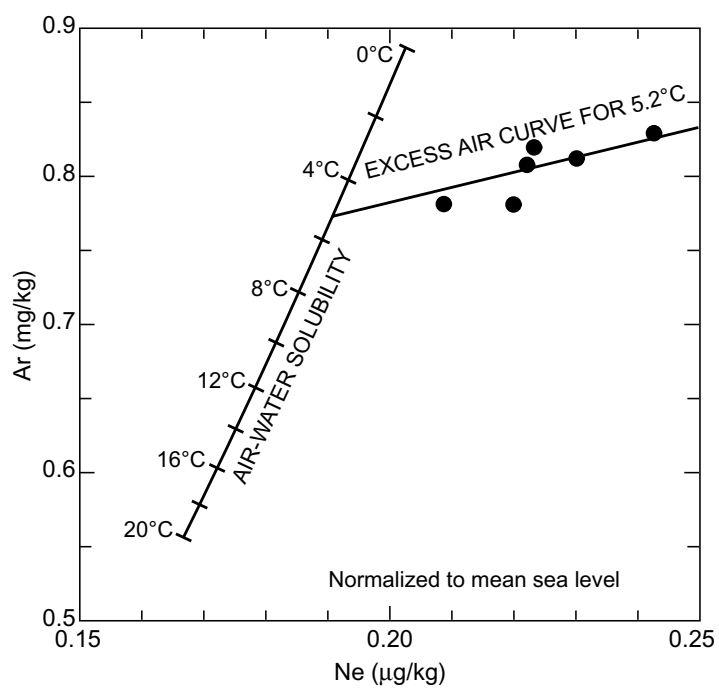

Figure $2 \mathrm{Ne}$ and Ar concentrations in ground water (transect sites at which $\mathrm{Ne}$ was measured), with air-water solubility curve (Weiss, 1970, 1971) and excess air trend for water recharged at $5.2^{\circ} \mathrm{C}$. Data normalized to mean sea level (US Committee on Extension to the Standard Atmosphere, 1976) to remove variability associated with variable recharge elevations, where recharge elevation for a given sample was assumed to be the water table elevation at the sampling site.

detectable sulfate $\left[\mathrm{SO}_{4}\right]$ ) could have led to microbial degradation of CFCs, and the CFC apparent age for this site was considered the maximum likely tracer-based apparent age. CFC apparent ages are presented in Table 2.

A subset of transect wells was sampled for ${ }^{3} \mathrm{H} /{ }^{3} \mathrm{He}$ ground-water dating (e.g. Schlosser et al., 1989; Cook and Solomon, 1997; Solomon and Cook, 2000). Calculated ${ }^{3} \mathrm{H} /{ }^{3} \mathrm{He}$ apparent ages are given in Table 2 . Diffusive ${ }^{3} \mathrm{He}$ loss can occur in ground water with vertical flow velocities of less than about $0.25-0.50 \mathrm{~m} / \mathrm{y}$, leading to a young bias in ${ }^{3} \mathrm{H} /{ }^{3} \mathrm{He}$ apparent ages (Schlosser et al., 1989). Low recharge rates in the study area (discussed below) likely result in low vertical flow velocities and may cause a young bias in ${ }^{3} \mathrm{H} /{ }^{3} \mathrm{He}$ apparent ages. Thus, ${ }^{3} \mathrm{H} /{ }^{3} \mathrm{He}$ apparent ages are interpreted as minimum ages. Although ${ }^{3} \mathrm{H} /{ }^{3} \mathrm{He}$ apparent ages are qualified (presented as minimum apparent ages), they are consistent with the CFC apparent ages, and thus provide support for the reliability of the CFC dating method.

Ground water from three deep transect sites (Burgess 6.2, Century 1.2, and Century 6.2) was dated only with ${ }^{3} \mathrm{H}$. In all three cases, ${ }^{3} \mathrm{H}$ concentrations were $\leqslant 0.2 \mathrm{TU}(\mathrm{Ta}$ ble 2), clearly indicating pre-bomb (pre-1953) recharge. This apparent age of $>47 \mathrm{y}$ represents travel time through both the (thin) unsaturated zone and saturated zone.

Burgess transect hydrochronology (as well as $\mathrm{O}_{2}, \mathrm{NO}_{3}$, and $\mathrm{Cl}$ distributions) are shown in Fig. 3. There is good agreement between tracer-based apparent ground-water ages and position along the transect - ground-water apparent age increases with depth and in the downgradient direction. The relatively small apparent age $(<34 \mathrm{y})$ at Burgess 6.1 (shallow well located adjacent to the Little Deschutes River) may reflect mixing of river and ground water.

In some types of simple aquifers, recharge rates may be estimated from individual tracer-based apparent ground- water ages by using the following equation (Vogel, 1967; Cook and Böhlke, 2000):

$\boldsymbol{R}=(\boldsymbol{H} \boldsymbol{\varepsilon} / \boldsymbol{T}) \ln (\boldsymbol{H} /(\boldsymbol{H}-\mathbf{z}))$

where $\boldsymbol{R}$ is the recharge rate, $\boldsymbol{H}$ the aquifer thickness, $\boldsymbol{\varepsilon}$ the porosity, $T$ the time of travel, and $z$ the depth below the water table. Eq. (1) holds for homogeneous, unconfined aquifers of constant thickness receiving uniform recharge. Eq. (1) was applied to the Burgess transect. (Shallow wells along the Century transect tap a 1- to 2-m sand layer underlain by about $10-20 \mathrm{~m}$ of clay; the $0.6-\mathrm{m}$ screened intervals were sufficiently long relative to the sand layer thickness that the Century transect wells were not amenable to use in Eq. (1).) Sites with censored CFC apparent ages (associated with a ">" or " $<$ ") were not used. Assuming an aquifer thickness of $15 \mathrm{~m}$ (typical saturated thickness of sands overlying fine-grained materials along the Burgess transect) and a porosity of 0.3 , Eq. (1) yields a median recharge rate of $5.4 \mathrm{~cm} / \mathrm{y}$, or about $12 \%$ of average annual precipitation. This recharge estimate is somewhat greater than the 3.6$3.8 \mathrm{~cm} / \mathrm{y}$ estimated for the Burgess transect area by regional application of a water balance model (Bauer and Vaccaro, 1987) to the upper Deschutes Basin (Boyd, 1996; Gannett et al., 2001), but comparable to the $5.1-5.4 \mathrm{~cm} / \mathrm{y}$ that provided the optimal fit during calibration of the aquifer-scale model accompanying the current study (Morgan et al., 2002). Note that a recharge rate of $5.4 \mathrm{~cm} / \mathrm{y}$ and a porosity of 0.3 equates to vertical velocity near the water table of $0.18 \mathrm{~m} / \mathrm{y}$ - sufficiently slow that incomplete ${ }^{3} \mathrm{He}$ confinement is possible, as described above.

The hydrochronology of ground water along the Century transect is consistent with the expectation that deeper ground water should generally be older than shallower ground water. The deep wells (Century 1.2 and 6.2, screened more than $15 \mathrm{~m}$ below the water table) contained pre-bomb water. The remaining wells were screened within $2 \mathrm{~m}$ of the water table, and yielded water with tracer-based apparent ground water ages of 9-23 y. Tracer-based apparent ages in the shallow Century transect wells do not vary in any obvious systematic manner along the transect. These shallow wells were installed along a narrow ridge in the potentiometric surface (Fig. 1), and ground water probably is shed laterally from this ridge with the result that shallow ground water collected along the length of the Century transect probably represents a collection of samples of locally recharged ground water and not a chronologic sequence of ground water.

Patterns of $\mathrm{NO}_{3}$ and $\mathrm{NH}_{4}$ distribution along the Burgess and Century transects (Fig. 3 and Table 1) are similar to those observed in the ODEQ synoptic network $-\mathrm{NO}_{3}$ is found at shallow depth, whereas $\mathrm{NH}_{4}$ is found in deeper ground water, or in downgradient ground water where regional ground water discharges towards rivers. $\mathrm{NO}_{3}$ is found only in younger water that may have been affected by recent anthropogenic inputs, whereas $\mathrm{NH}_{4}$ occurs primarily in older water that predates most anthropogenic activities in the area (Fig. 4).

\section{Sources of $\mathrm{NO}_{3}$ and $\mathrm{NH}_{4}$}

ODEQ synoptic network $\mathrm{NO}_{3}$ and $\mathrm{Cl}$ data, along with potential endmember sources of $\mathrm{N}$ and $\mathrm{Cl}$ (atmospheric precipitation 


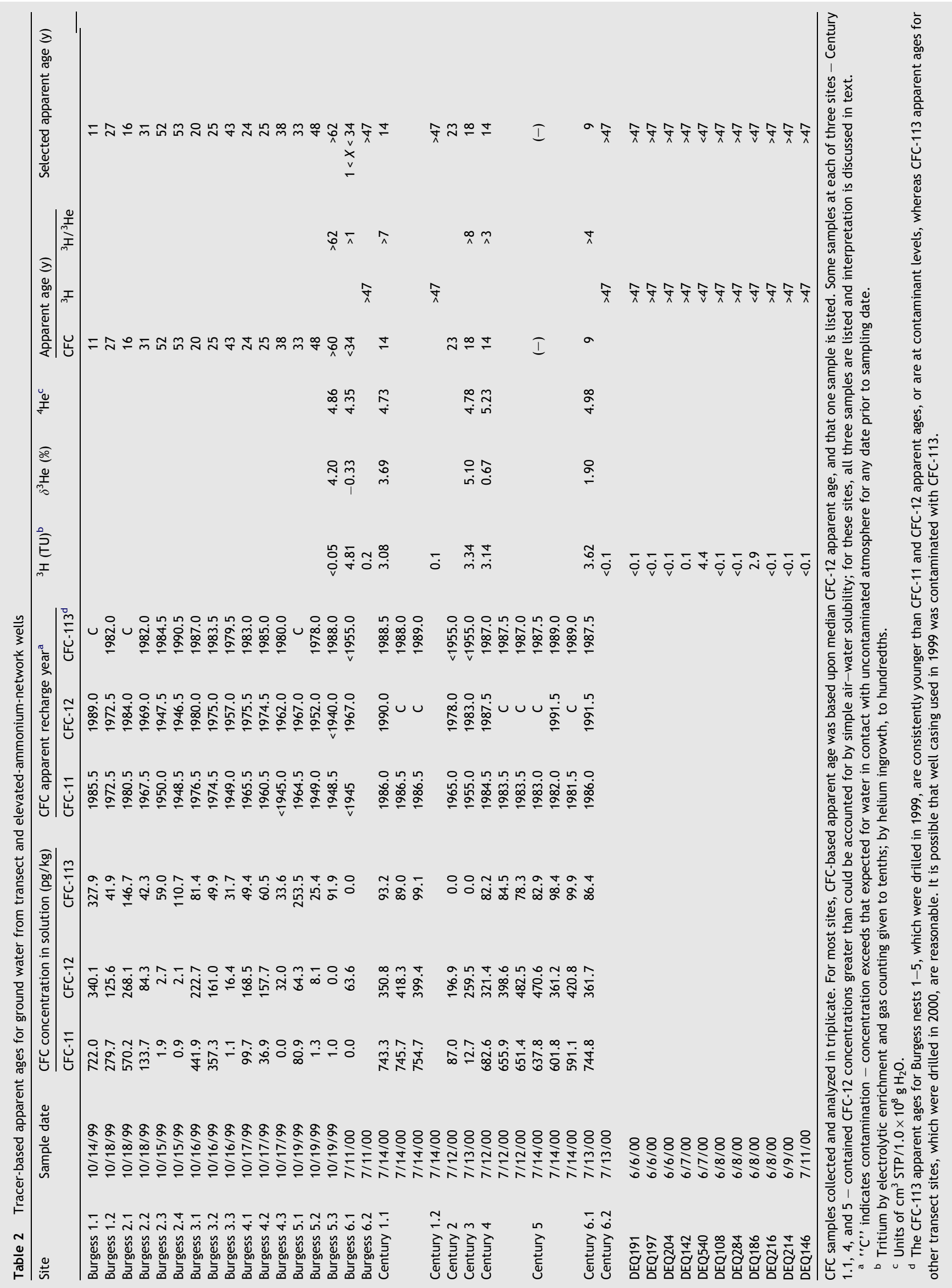




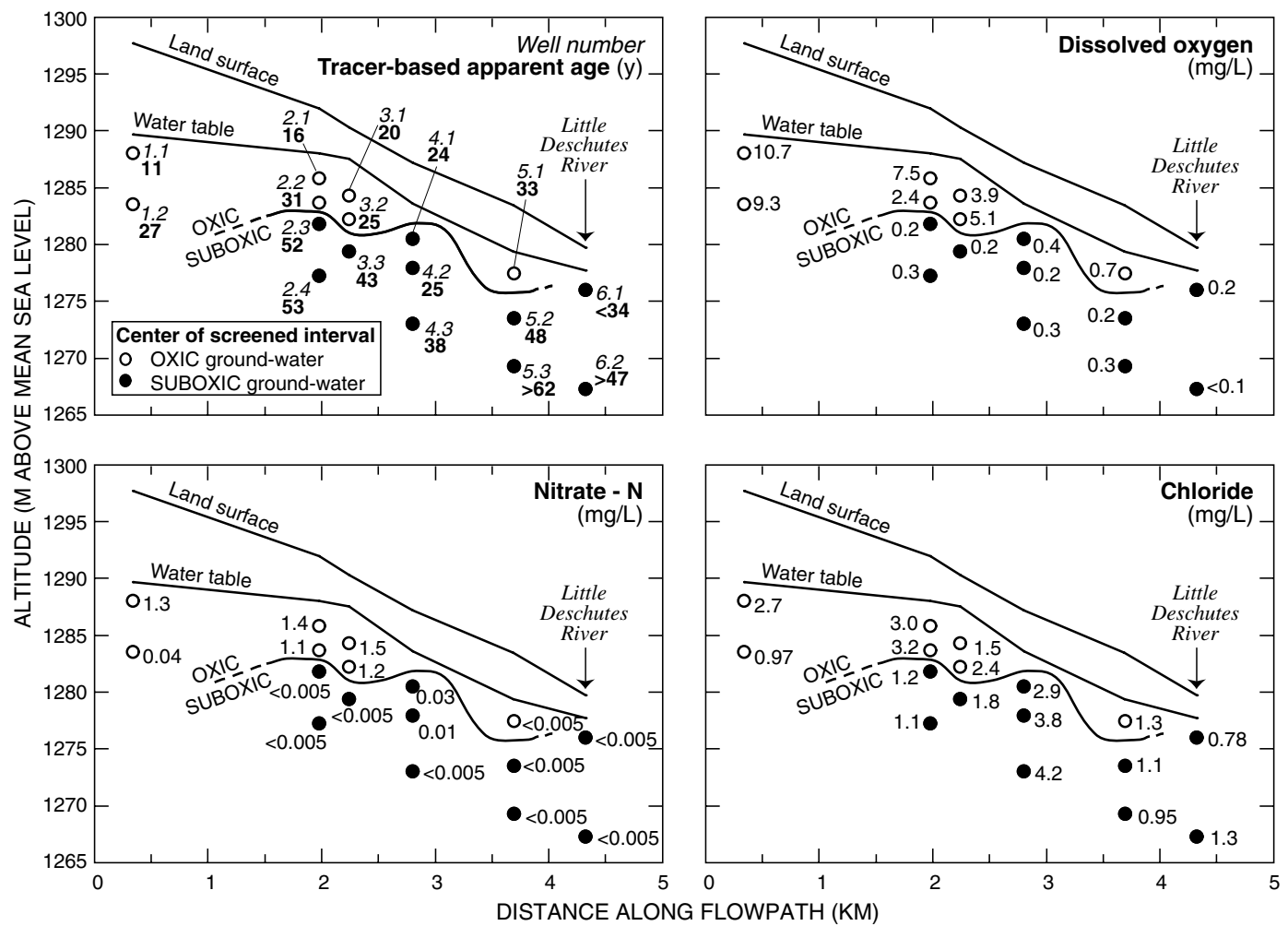

Figure 3 Tracer-based apparent ground-water ages, and $\mathrm{O}_{2}, \mathrm{NO}_{3}$, and $\mathrm{Cl}$ concentrations, along Burgess transect. Ground water moves down and towards the right, and discharges to the Little Deschutes River.

data and typical septic tank effluent values), are shown in Fig. 5. Atmospheric precipitation $\mathrm{N}$ and septic tank effluent $\mathrm{N}$ are shown in Fig. 5 as equivalent $\mathrm{NO}_{3}$; that is, atmospheric $\mathrm{NH}_{4}$ was combined with atmospheric $\mathrm{NO}_{3}$ and plotted as equivalent $\mathrm{NO}_{3}$, and septic tank $\mathrm{N}$ was plotted assuming all reduced $\mathrm{N}$ was oxidized to $\mathrm{NO}_{3}$. Median $\mathrm{N}$ and $\mathrm{Cl}$ concentrations from study area septic tank effluent $(55 \mathrm{~N}, 32 \mathrm{Cl}$ samples; Rich, 2001) are plotted as a point in Fig. 5. Other data on typical septic tank effluent from the literature (US Environmental Protection Agency, 1978; Oregon Department of Environmental Quality, 1982; Alhajjar et al., 1989; Bushman, 1996; Bunnell et al., 1999; Bates, 2000) are included in the error bars in Fig. 5, which represent the ranges of medians (means if medians not provided) from these literature sources. The wider range in these literature values for $\mathrm{Cl}$ compared to $\mathrm{N}$ may reflect variations in $\mathrm{Cl}$ concentrations due to presence or absence of water softeners, and variations in $\mathrm{Cl}$ concentrations in sources of domestic water resulting from, for example, factors such as proximity to coastal environments, local use of road salt, or variations in evapotranspiration.

Concentrations of both $\mathrm{N}$ and $\mathrm{Cl}$ are higher in septic tank effluent than in ODEQ synoptic network ground-water $\mathrm{NO}_{3}$ and $\mathrm{Cl}$ samples (Fig. 5). Septic tank effluent is likely the primary source of elevated $\mathrm{Cl}$ in La Pine ground water. Evaporites do not occur in the volcanic rocks and sediment of the study area, and agricultural sources of $\mathrm{Cl}$ are not important ("Study area and background" section). Sodium chloride is not used on roads, and although compounds containing magnesium chloride are occasionally used, their use is limited and spatially restricted in the study area (Hinkle et al., 2005). For these reasons, and because $\mathrm{Cl}$ is nonreactive, $\mathrm{Cl}$ is a useful tracer of septic tank effluent in the La Pine area. Most of the ODEQ synoptic network data plot near a mixing line in Fig. 5 between the region representing precipitation (allowing for varying degrees of evapotranspiration and vegetative nutrient uptake) and a region of $\mathrm{N}$ - and $\mathrm{Cl}$ rich septic tank effluent. Low $-\mathrm{O}_{2}$ samples plotting primarily below the mixing region will be discussed in the next section. Thus, $\mathrm{NO}_{3} / \mathrm{Cl}$ relations in Fig. 5 are consistent with a septic tank effluent source of elevated $\mathrm{NO}_{3}$ concentrations. In addition, the observation that ODEQ synoptic network detections of $\mathrm{NO}_{3}>1 \mathrm{mg} / \mathrm{L} \mathrm{NO}_{3}-\mathrm{N}$ occur near the water table is consistent with, although not uniquely indicative of, septic tank effluent being the dominant anthropogenic source of $\mathrm{NO}_{3}$ in the study area.

Geochemical data along the Burgess and Century transects also point to a septic tank effluent source of $\mathrm{NO}_{3}$ (and $\mathrm{Cl}$ ) to study area ground water (Fig. 3, and Tables 1 and 2). In general, concentrations of $\mathrm{NO}_{3}$ and $\mathrm{Cl}$ are greater in ground water with apparent ages $<40$ y $\left(\mathrm{NO}_{3}-\mathrm{N}\right.$ up to $6.7 \mathrm{mg} / \mathrm{L}, \mathrm{Cl}$ up to $13 \mathrm{mg} / \mathrm{L}$ ) than in ground water with apparent ages $>40$ y $\left(\mathrm{NO}_{3}-\mathrm{N}<0.01 \mathrm{mg} / \mathrm{L}, \mathrm{Cl} \leqslant 3.0 \mathrm{mg} / \mathrm{L}\right)$. These data indicate relatively recent loading of both $\mathrm{NO}_{3}$ and $\mathrm{Cl}$, consistent with the history of home construction along the transects.

Ground-water $\mathrm{NO}_{3}$ concentrations from the dispersion array, a dense network of wells in a $730 \times 6.4 \mathrm{~m}$ plane oriented perpendicular to the Burgess transect, are shown in Fig. 6. $\mathrm{NO}_{3}$ and $\mathrm{Cl}$ (data not shown) are correlated 

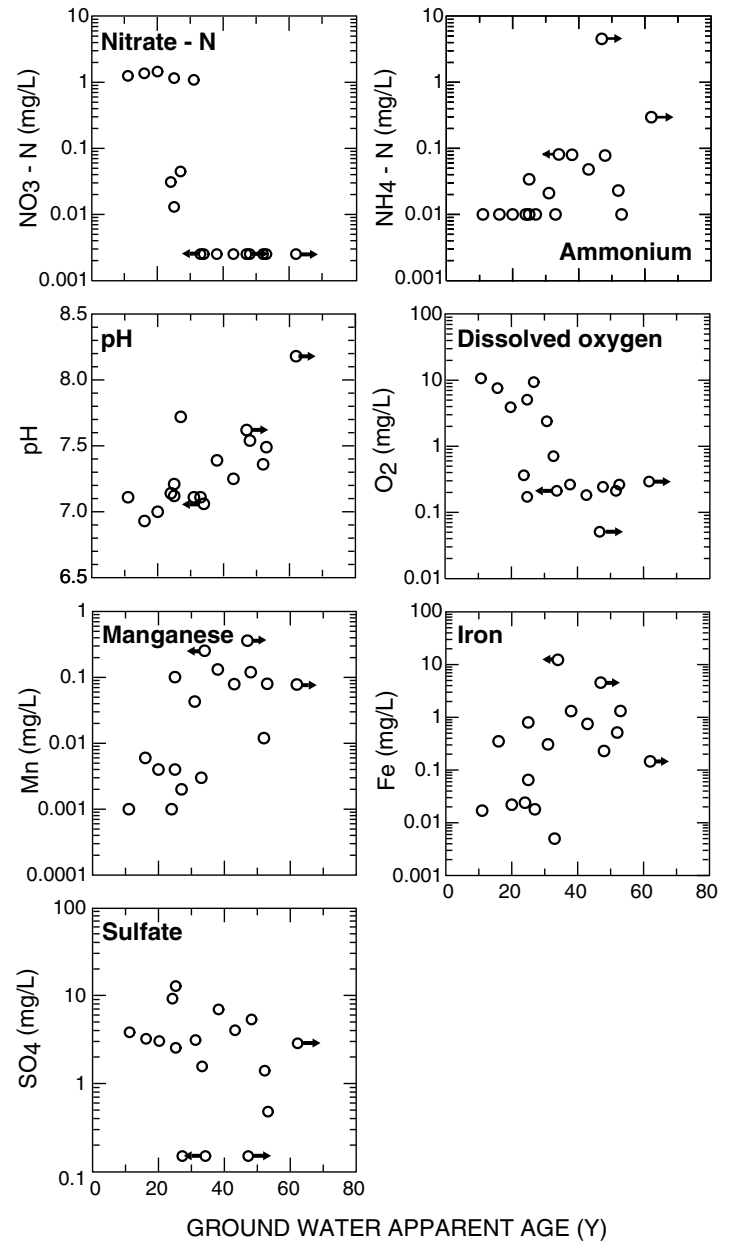

Figure $4 \mathrm{NO}_{3}, \mathrm{NH}_{4}, \mathrm{pH}, \mathrm{O}_{2}, \mathrm{Mn}$, $\mathrm{Fe}$, and $\mathrm{SO}_{4}$ concentrations along Burgess Transect, as function of tracer-based apparent ground-water age. Arrows indicate censored apparent ages, where a right arrow indicates that apparent age is greater than plotted age, and a left arrow indicates that apparent age is less than plotted age. Concentrations below detection limit plotted at half the detection limit.

$\left(r^{2}=0.77, p<0.0001\right) . \mathrm{NH}_{4}-\mathrm{N}$ concentrations (data not shown) for the 32 sites were low, with a median of $0.02 \mathrm{mg} / \mathrm{L}$ and a maximum of $0.07 \mathrm{mg} / \mathrm{L}$. $\mathrm{NO}_{3}$ occurs in discrete plumes, each of which could represent a plume from an individual septic tank drainfield, or the coalescing of plumes from several distinct drainfields. The heterogeneous distribution of $\mathrm{NO}_{3}$ concentrations is consistent with a number of point sources of septic-tank-derived $\mathrm{NO}_{3}$, rather than a uniform nonpoint source such as from agricultural sources, and provides additional support for a septic-tank source of $\mathrm{NO}_{3}$ in the study area. The occurrence of low to modest $\mathrm{NO}_{3}$ concentrations along the Burgess transect (Table 1) may be understood in the context of the dispersion array if upgradient Burgess transect wells tap ground water primarily from locations either between or below $\mathrm{NO}_{3}$ plumes.

The elevated concentrations of $\mathrm{NH}_{4}$ in many of the study area ground-water samples are unusual. Although $\mathrm{N}$ in septic tank effluent is predominantly in the form of $\mathrm{NH}_{4}$, reduced forms of $\mathrm{N}$ in septic tank effluent are rapidly oxidized to $\mathrm{NO}_{3}$ in the unsaturated zone in the drainfields

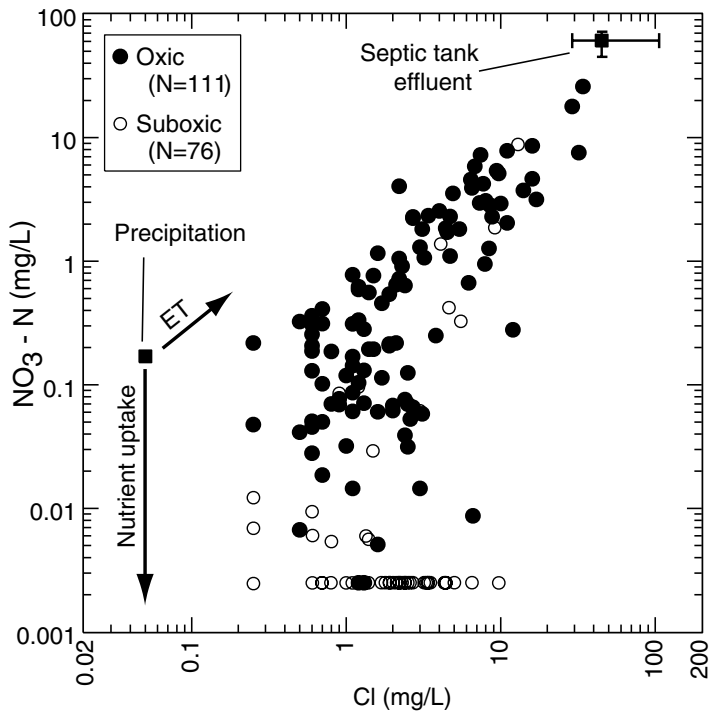

Figure $5 \quad \mathrm{NO}_{3}$ and $\mathrm{Cl}$ concentrations from ODEQ aquifer-scale synoptic. End-member mixing components are septic tank effluent and atmospheric precipitation; see text for discussion of these components. ODEQ synoptic samples are interpreted to represent a mixture of precipitation and septic tank effluent, where precipitation may be subject to enrichment by evapotranspiration (ET) and to vegetative $\mathrm{NO}_{3}$ uptake (arrows). Low $\mathrm{NO}_{3}$ concentrations in most suboxic samples are interpreted to represent effects of denitrification in the saturated zone. Square symbols showing septic tank effluent and unevaporated precipitation represent total nitrogen (septic tank effluent) or $\mathrm{NO}_{3}+\mathrm{NH}_{4}$ (atmospheric precipitation) plotted as equivalent $\mathrm{NO}_{3}$. Concentrations below detection limit plotted at half the detection limit.

(Walker et al., 1973; Robertson and Cherry, 1992; MacQuarrie et al., 2001). Subsequent reduction of $\mathrm{NO}_{3}$ in downgradient reducing regions of an aquifer could yield either $\mathrm{NH}_{4}$ or $\mathrm{N}_{2}$, but reduction to $\mathrm{NH}_{4}$ is generally for assimilative pur-

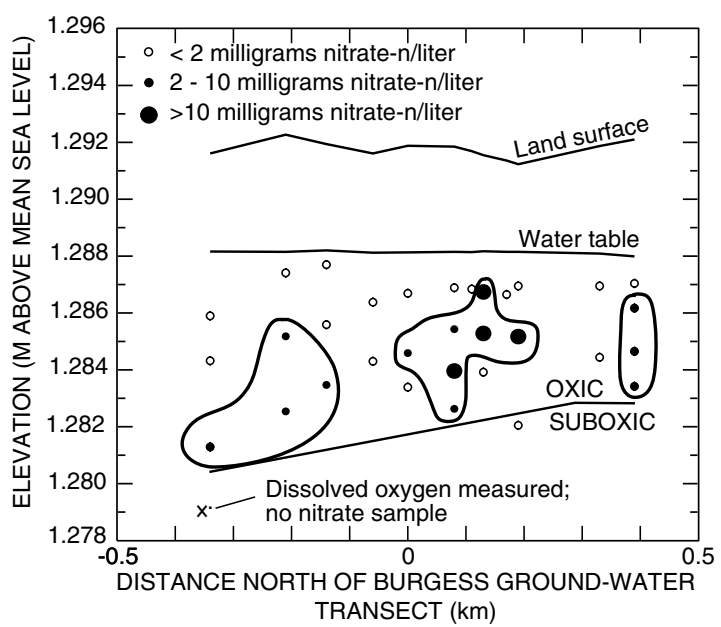

Figure 6 Dispersion array of ground-water samples. Array oriented perpendicular to Burgess transect at second nest (at flowpath distance of $2.0 \mathrm{~km}$ in Fig. 3). Ground water flow is out of page towards reader. $\mathrm{NO}_{3}$ is present in isolated plumes. 
poses (Brock and Madigan, 1988), and most $\mathrm{NO}_{3}$ reduction in flowing ground water has been attributed to dissimilative reduction to $\mathrm{N}_{2}$ (Freeze and Cherry, 1979). Elevated concentrations of $\mathrm{NH}_{4}$ observed in the ODEQ synoptic network tended to be deep or (apparently) near the ends of ground-water flowpaths, consistent with either $\mathrm{NO}_{3}$ reduction or a natural, possibly sedimentary organic matter source for the $\mathrm{NH}_{4}$, perhaps associated with the lacustrine deposits that underlie the primary aquifer. However, the low $\mathrm{Cl}$ concentrations of $\mathrm{NH}_{4}$-rich ODEQ synoptic ground water (Fig. 7) point to a source other than septic tank effluent for the elevated concentrations of $\mathrm{NH}_{4}$. That is, the $\mathrm{Cl}$ data make it highly unlikely that the $\mathrm{NH}_{4}$ could have originated directly from septic tank $\mathrm{N}$, or by oxidation of septic tank $\mathrm{N}$ to $\mathrm{NO}_{3}$ with subsequent, downgradient reduction to $\mathrm{NH}_{4}$. A similar conclusion is indicated by data from the Burgess and Century transects, where elevated concentrations of $\mathrm{NH}_{4}$ are associated with low-Cl ground water (Fig. 7), and are found in downgradient (Fig. 3 and Table 1), older (Fig. 4 and Table 2) ground water. The $\mathrm{Cl}$ data, therefore, are inconsistent with a septic tank source for the elevated $\mathrm{NH}_{4}$. A more likely possibility is that $\mathrm{NH}_{4}$ is derived from natural sedimentary organic matter.

Additional insight into the origin of the $\mathrm{NH}_{4}$ is provided by detailed analyses of ground water from 11 sites with elevated concentrations of $\mathrm{NH}_{4}$ (Tables 1 and 2). These samples contain high concentrations of Fe (median $1.6 \mathrm{mg} / \mathrm{L}$ ) and $\mathrm{CH}_{4}$ (median $74 \mathrm{mg} / \mathrm{L}$ for a subset of eight samples), reflecting highly reducing conditions that typically accompany organic matter degradation. These samples also contain elevated concentrations of $P$ (median $2.1 \mathrm{mg} / \mathrm{L}$ ), which might have been mobilized during organic matter degradation. Total carbon $(C)$ and total $N$ for the subset of these sites at which dissolved gases were analyzed are well correlated, with $r^{2}=0.85$ and $\mathrm{C}: \mathrm{N}$ mass ratio of 6.0 (slope of "line of organic correlation", for functional relationships in which neither variable is the independent variable; Helsel and Hirsch, 1992). For this correlation, total $C$ was defined to be inorganic carbon $+\mathrm{DOC}+\mathrm{CH}_{4}$, and total $\mathrm{N}$ was defined to be Kjeldahl $\mathrm{N}+\mathrm{NO}_{3} \quad\left(\mathrm{~N}_{2}\right.$ excluded because largely of atmospheric origin). Because carbonate phases are not

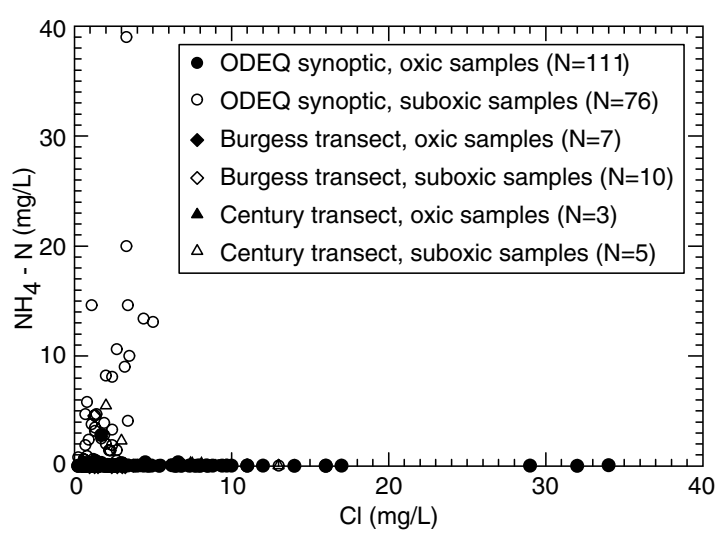

Figure $7 \quad \mathrm{NH}_{4}$ and $\mathrm{Cl}$ concentrations from transects and ODEQ aquifer-scale synoptic. Elevated concentrations of $\mathrm{NH}_{4}$ are associated with low $\mathrm{Cl}$ concentrations, indicative of a natural, presumably sedimentary source of $\mathrm{NH}_{4}$. Elevated concentrations of $\mathrm{NH}_{4}$ also tend to be suboxic. known to be present in the aquifer, the observed correlation is consistent with an organic matter source of $\mathrm{N}$ (C: $\mathrm{N}$ of photosynthetic organic matter is typically 106:16 on a molar basis, or about $5.7: 1$ on a mass ratio basis). Finally, ${ }^{3} \mathrm{H}$ concentrations mostly are $\leqslant 0.1$ TU (Table 2 ), reflecting dominantly pre-bomb ground water that is less likely to have received inputs of anthropogenic $\mathrm{N}$ than would more recently recharged ground water.

$\mathrm{N}$ isotopes can be useful locally in identifying $\mathrm{N}$ sources. For example, $\delta^{15} \mathrm{~N}$ values of $\mathrm{NO}_{3}$ derived from wastewater sources typically are $>5 \%$, but $<5 \%$ for $\mathrm{NO}_{3}$ derived from natural soil organic matter (Fogg et al., 1998). The $\delta^{15} \mathrm{~N}-$ $\mathrm{NO}_{3}$ values from shallow ground water along transects are, for the most part, both similar to $\delta^{15} \mathrm{~N}-\mathrm{NO}_{3}$ values from septic tank effluent plumes, and distinct from $\delta{ }^{15} \mathrm{~N}-\mathrm{NH}_{4}$ values for elevated- $\mathrm{NH}_{4}$ network sites and transect sites with elevated $\mathrm{NH}_{4}$ concentrations (Fig. 8). Two samples did have $\delta{ }^{15} \mathrm{~N}-\mathrm{NO}_{3}$ values $<5 \%$. $\mathrm{NO}_{3}$ in these samples could represent $\mathrm{NO}_{3}$ that is, at least in part, of natural origin. Alternatively, fractionation of septic-tank-derived $\mathrm{N}$ during $\mathrm{NH}_{4}$ nitrification in the unsaturated zone beneath drainfields upgradient from these two sites, in combination with sorption of a portion of the $\mathrm{NH}_{4}$, could result in isotopically depleted aqueous $\mathrm{NO}_{3}$ (Hübner, 1986). These two samples notwithstanding, the overall similarity between the $\delta^{15} \mathrm{~N}-\mathrm{NO}_{3}$ values from shallow ground water along transects and those representing septic tank effluent further support the concept of septic tank effluent being the predominant $\mathrm{NO}_{3}$ source in study area ground water. Furthermore, differences between $\delta^{15} \mathrm{~N}-\mathrm{NO}_{3}$ values of transect and septic tank effluent plume samples on the one hand, and $\delta^{15} \mathrm{~N}-\mathrm{NH}_{4}$ values of high- $\mathrm{NH}_{4}$ ground-water samples on the other, indicate that the source of elevated concentrations of $\mathrm{NH}_{4}$ is distinct from that of most of the $\mathrm{NO}_{3}$. The isotopic data are inconsistent with transport and subsequent reduction of septic-tank-derived $\mathrm{NO}_{3}$ to $\mathrm{NH}_{4}$ because reduction of all of the $\mathrm{NO}_{3}$ to $\mathrm{NH}_{4}$ would yield $\delta^{15} \mathrm{~N}-\mathrm{NH}_{4}$ values greater than those observed. Reduction of only a portion of the $\mathrm{NO}_{3}$ to

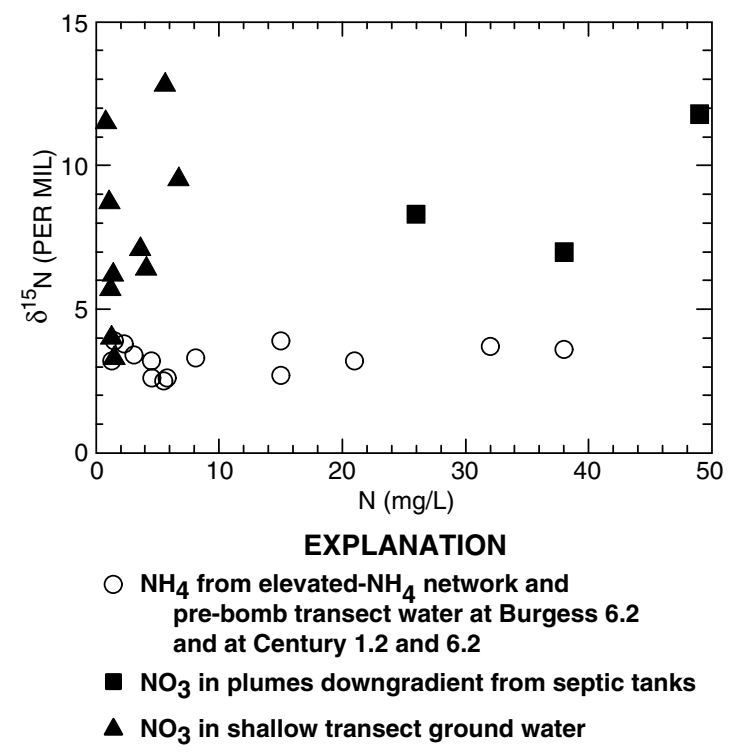

Figure 8 Nitrogen concentrations and $\delta^{15} \mathrm{~N}$ values for study area ground water. 
$\mathrm{NH}_{4}$, with kinetic fractionation, could yield smaller $\delta^{15} \mathrm{~N}-$ $\mathrm{NH}_{4}$ values, but would be unlikely to yield consistently such a small range of $\delta^{15} \mathrm{~N}-\mathrm{NH}_{4}$ values $(2.5-3.9 \%$ ) across a large range of $\mathrm{NH}_{4}-\mathrm{N}$ concentrations $(1.3-38 \mathrm{mg} / \mathrm{L})$. It also would be difficult to reconcile the highest concentrations of $\mathrm{NH}_{4}-\mathrm{N}$ (up to $38 \mathrm{mg} / \mathrm{L}$ ) with only partial reduction of $\mathrm{NO}_{3}$ to $\mathrm{NH}_{4}$. On the other hand, $\delta^{15} \mathrm{~N}-\mathrm{NH}_{4}$ values are similar to those of aquifer sediments from the study area, which decrease with increasing $\mathrm{N}$ content and level off asymptotically at about $2-3 \%$ at higher $\mathrm{N}$ concentrations (provided as Supplemental data: supplemental_data_4.doc). Thus, the isotopic data are interpreted as additional evidence for a natural, sedimentary source of elevated aqueous $\mathrm{NH}_{4}$ concentrations as mineralization of organic $\mathrm{N}$ may be accompanied by relatively little isotopic fractionation (Högberg, 1997; Kendall and Aravena, 2000).

\section{Evidence for denitrification}

Denitrification is the dominant $\mathrm{NO}_{3}$ sink in most groundwater systems (Kinzelbach et al., 1991; Postma et al., 1991). Denitrification is inhibited by the presence of $\mathrm{O}_{2}$ (Brock and Madigan, 1988), but once $\mathrm{O}_{2}$ is consumed, denitrification is thermodynamically favored. Denitrification in aquifers commonly is coupled to oxidation of organic carbon:

$$
1.25 \mathrm{CH}_{2} \mathrm{O}+\mathrm{NO}_{3}^{-}=0.5 \mathrm{~N}_{2}+1.25 \mathrm{HCO}_{3}^{-}+0.25 \mathrm{H}^{+}+0.5 \mathrm{H}_{2} \mathrm{O}
$$

where $\mathrm{CH}_{2} \mathrm{O}$ represents organic carbon. $\mathrm{NO}_{3}$ can also be denitrified by other electron donors, notably Fe sulfide $\left(\mathrm{FeS}_{2}\right)$ and other ferrous Fe phases (Kölle et al., 1985; Postma et al., 1991; Robertson et al., 1996; Straub et al., 1996; McMahon et al., 1999; Böhlke et al., 2002).

$\mathrm{N}_{2}$ and Ar concentrations were used to assess the distribution of denitrification in the ground water. Concentrations of $\mathrm{N}_{2}$ and Ar from the Burgess and Century transects (Fig. 9, top) plot near or to the right of the curve representing $5.2{ }^{\circ} \mathrm{C}$ recharge with varying amounts of excess air (Heaton and Vogel, 1981). Offset to the right (high $\mathrm{N}_{2}$ ) side of the excess air curve may reflect recharge at temperatures $>5.2{ }^{\circ} \mathrm{C}$ for some samples. However, $\mathrm{N}_{2}$ concentrations in several samples cannot be accounted for simply by warmer recharge temperatures, as the offsets in Fig. 9 are too great for an area with a mean annual air temperature of $7.2^{\circ} \mathrm{C}$ or a mean annual soil temperature of around $8.2^{\circ} \mathrm{C}$, even if we disregard the fact that recharge occurs mainly from late fall through early spring. Furthermore, the presence of isotopically enriched $\mathrm{N}_{2}\left(\delta^{15} \mathrm{~N}-\mathrm{N}_{2}>1.0 \%\right)$ in four samples provides evidence that some of this $\mathrm{N}_{2}$ was nonatmospheric in origin. Dissolved $\mathrm{N}_{2}$ in equilibrium with air will be enriched in ${ }^{15} \mathrm{~N}$ relative to AIR by about $0.8 \%$ at a recharge temperature of $5.2^{\circ} \mathrm{C}$ (Klots and Benson, 1963), whereas $\mathrm{N}_{2}$ from excess air will be close to $0.0 \%$. $\mathrm{N}$ is fractionated isotopically during denitrification, with product $\mathrm{N}_{2}$ having lower $\delta^{15} \mathrm{~N}$ than reactant $\mathrm{NO}_{3}$. However, when denitrification goes to completion (complete conversion from $\mathrm{NO}_{3}$ to $\mathrm{N}_{2}$ ) in a closed system, the $\delta^{15} \mathrm{~N}$ value of the $\mathrm{N}_{2}$ produced by denitrification will be equal to that of the original $\mathrm{NO}_{3}$ reactant. Given the range of $\delta^{15} \mathrm{~N}$ values observed in study area $\mathrm{NO}_{3}, 3.3-12.8 \%$ (Fig. 8), $\delta^{15} \mathrm{~N}-\mathrm{N}_{2}$ values $>1.0 \%$ in samples with little or no remaining $\mathrm{NO}_{3}$ constitute evidence for denitrification, and
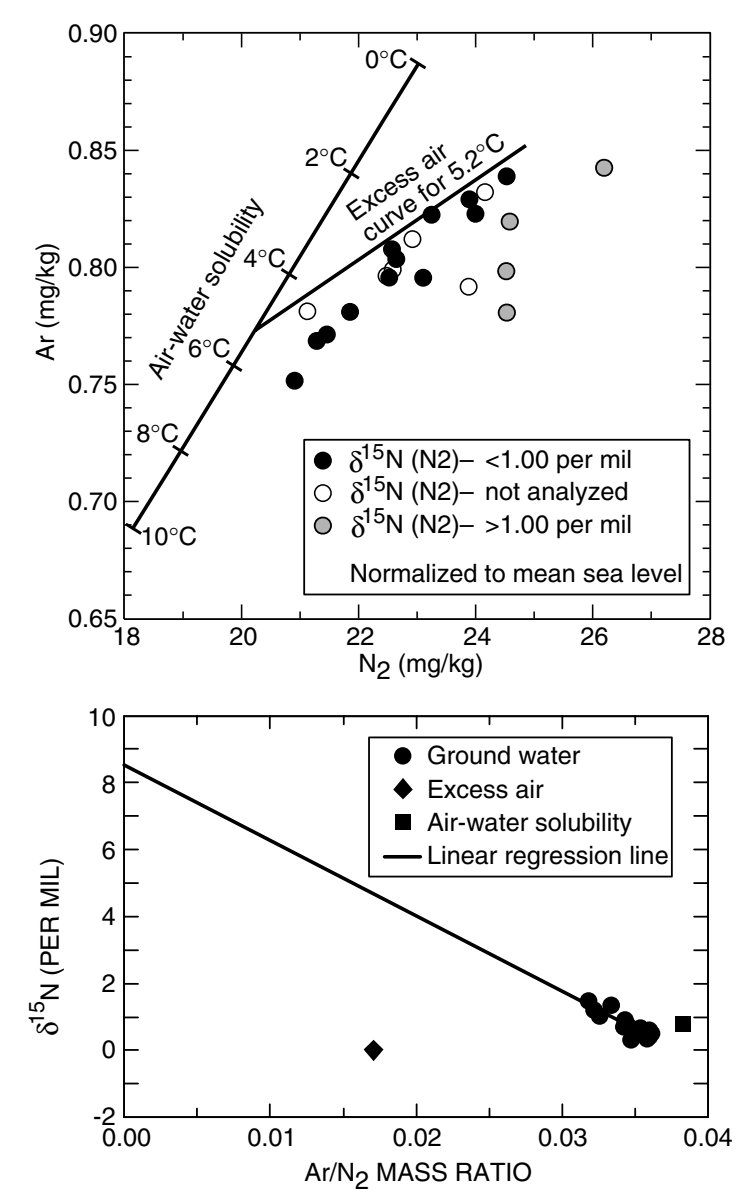

Figure 9 Top, $\mathrm{N}_{2}$ and Ar concentrations in ground water, with air-water solubility curve (Weiss, 1970) and excess air trend. Data normalized to mean sea level (US Committee on Extension to the Standard Atmosphere, 1976). Isotopically enriched $N_{2}$ is interpreted to contain a component of $\mathrm{NO}_{3}$ that has been quantitatively denitrified. Bottom, $\mathrm{Ar} / \mathrm{N}_{2}$ ratios and $\delta{ }^{15} \mathrm{~N}$ values for ground water and two recharge components consisting of air-water solubility $\left(5.2^{\circ} \mathrm{C}\right)$ and excess air $\left(\delta^{15} \mathrm{~N}\right.$ values for these components discussed in text). $\mathrm{N}_{2}$ in ground water appears to be composed of a mixture of $\mathrm{N}_{2}$ derived from airwater solubility and excess air, with some samples containing additional, isotopically enriched $\mathrm{N}_{2}$. A linear regression line through the ground-water samples can be extrapolated to an $\mathrm{N}_{2}$ end-member with $\delta^{15} \mathrm{~N}$ about $8.5 \%$, consistent with a source as denitrified $\mathrm{NO}_{3}$ of septic-tank origin.

represent denitrification of a few $\mathrm{mg} / \mathrm{L} \mathrm{NO} \mathrm{N}_{3}-\mathrm{N}$. Generally increasing $\delta{ }^{15} \mathrm{~N}-\mathrm{N}_{2}$ values with decreasing $\mathrm{Ar} / \mathrm{N}_{2}$ ratios, with a trend towards an $\mathrm{N}_{2}$ end-member with $\delta^{15} \mathrm{~N}$ of about $8.5 \%$, also supports denitrification of septic-tank-derived $\mathrm{NO}_{3}$ (Fig. 9, bottom).

The relation between $\mathrm{NO}_{3}$ and $\mathrm{Cl}$ from the ODEQ synoptic network (Fig. 5) is interpreted to indicate mixing of $\mathrm{NO}_{3}$ and $\mathrm{Cl}$ from two sources, with departure from this mixing zone explained by $\mathrm{NO}_{3}$ loss in suboxic $\left(\mathrm{O}_{2}<0.5 \mathrm{mg} / \mathrm{L}\right)$ ground water. Although vegetative uptake of $\mathrm{NO}_{3}$ might occur locally where the water table is near land surface, this process cannot explain the widespread $\mathrm{NO}_{3}$ loss implied by Fig. 5. Similarly, although reduction of $\mathrm{NO}_{3}$ to $\mathrm{NH}_{4}$ could 
occur locally, spatial, temporal, and isotopic data are inconsistent with reduction of $\mathrm{NO}_{3}$ to $\mathrm{NH}_{4}$ ("Sources of $\mathrm{NO}_{3}$ and $\mathrm{NH}_{4}$ "' section). Denitrification is considered to be the major mechanism for $\mathrm{NO}_{3}$ loss in the suboxic ODEQ synoptic network samples.

Progressive geochemical evolution is evident in the Burgess transect data (Figs. 3 and 4). Increases in $\mathrm{pH}$ with increases in tracer-based apparent age reflect progression of kinetically slow hydrolysis reactions. Younger, upgradient ground water typically is oxic, with suboxic conditions developing after about 30 y of transport below the water table. $\mathrm{NO}_{3}$ tends to be found in younger, upgradient ground water, whereas older water is essentially $\mathrm{O}_{2}$ and $\mathrm{NO}_{3}$ free. In general, concentrations of manganese $(\mathrm{Mn})$ and $\mathrm{Fe}$ are higher in older ground water than in younger ground water, whereas $\mathrm{SO}_{4}$ concentrations tend to be lower in older ground water than in younger ground water. These data reflect progression to increasingly reducing conditions as ground-water residence time increases. It appears that denitrification goes essentially to completion in the vicinity of the oxic/suboxic boundary. Similar patterns are evident in the Century transect data, with suboxic conditions developing after about $15 \mathrm{y}$ of transport below the water table (Tables 1 and 2). As was observed in ODEQ synoptic network samples, $\mathrm{NO}_{3}$ along the Burgess and Century transects generally is not present at concentrations $>1 \mathrm{mg} / \mathrm{L} \mathrm{NO}_{3}-\mathrm{N}$ in suboxic ground water. Of the suboxic transect sites, only Century 5 (screened between 0.85 and $1.43 \mathrm{~m}$ of the water table) contained $>1 \mathrm{mg} / \mathrm{L} \mathrm{NO}_{3}-\mathrm{N}$. Thus, older ground water along these transects is largely $\mathrm{NO}_{3}$-free because of a combination of (1) smaller $N$ loadings at earlier time and (2) denitrification during geochemical evolution.

The dominant electron donor for study area denitrification reactions has not been identified. DOC is not likely to be an important electron donor for these reactions. DOC concentrations along the Burgess transect do not change systematically with ground-water evolution (Table 1), indicating little DOC consumption. Other studies also have noted that aqueous reductants generally play a minor role in denitrification reactions compared to the role played by solid phases (Kinzelbach et al., 1991; Postma et al., 1991; Böhlke and Denver, 1995; Aravena and Robertson, 1998; Böhlke et al., 2002). Even portions of aquifers directly receiving septic tank effluent generally do not receive sufficient DOC to balance denitrification, as organic carbon from septic tank effluent is efficiently oxidized in the unsaturated zone (Wilhelm et al., 1994; MacQuarrie et al., 2001; also, one of the samples from septic tank effluent plumes was analyzed for DOC, and at $2.2 \mathrm{mg} / \mathrm{L}$ (Table 1 ), suggests low DOC loading to the aquifer). Sedimentary organic carbon (SOC), on the other hand, could be a potential electron donor for denitrification as well as for other redox reactions. SOC is a common component of alluvial sediment. Furthermore, a sediment core penetrating the boundary between oxic and suboxic ground water exhibited an increase in SOC beneath the oxic/suboxic boundary $6.0 \mathrm{~m}$ below land surface (Hinkle et al., 2005). Excluding the uppermost layer of the core, which contains soil with plant detritus and thus is not representative of the organic carbon content of the aquifer, the core-layer-thickness-weighted organic carbon concentration of the sediment in the oxic zone was $<0.07 \%$, whereas that of the suboxic zone was $0.13 \%$, indi- cating that the SOC was an electron donor at this redox boundary. Alternatively, ferrous $\mathrm{Fe}$ in volcanic sediment could be an electron donor in some study-area redox reactions, and other electron donors cannot be ruled out. Our solid-phase data do not allow definitive identification of electron donors.

\section{A redox boundary approach for representing denitrification}

Data from the ODEQ synoptic network demonstrate that $\mathrm{NO}_{3}$ reactivity closely parallels $\mathrm{O}_{2}$ reactivity and indicate that denitrification proceeds quickly once $\mathrm{O}_{2}$ is consumed (Fig. 5). Of 76 suboxic ODEQ synoptic network samples, only three contained $>1 \mathrm{mg} / \mathrm{L} \mathrm{NO}_{3}-\mathrm{N}$. These samples were from shallow wells (screened within $7 \mathrm{~m}$ of the water table), and probably represent conditions in which $\mathrm{O}_{2}$ already had been reduced and in which denitrification was the dominant redox reaction. With only three of the suboxic samples representing the denitrification zone and the remaining 73 representing more reduced conditions, it would appear that the denitrification zone is narrow, and that the redox gradient near the oxic/suboxic boundary is sharp. It is also worth noting that the three suboxic sites with $>1 \mathrm{mg} / \mathrm{L} \mathrm{NO}_{3}-\mathrm{N}$ did not yield consistent results when sampled by ODEQ on three other occasions during 1999-2001. $\mathrm{NO}_{3}-\mathrm{N}$ concentrations were variable at these sites, and at times dropped below $1 \mathrm{mg} / \mathrm{L}$ at two sites. These data may indicate varying contributions of undenitrified and denitrified water from above and below a sharp redox boundary at or near the depth of the well screen.

An abrupt redox transition also is evident in the Burgess transect data (Fig. 3). There, the boundary between oxic and suboxic ground water is constrained by well placement to somewhere within a zone of about $2-3 \mathrm{~m}$, and, within the resolution of the scale of well placement, $\mathrm{NO}_{3}$ occurs essentially only on the oxic side of that boundary. Also, the apparent absence of ${ }^{15} \mathrm{~N}$-depleted $\mathrm{N}$ in $\mathrm{N}_{2}$ (Fig. 9) indicates a relative paucity of intermediate-stage denitrification that would be expected to accompany slowly denitrifying $\mathrm{NO}_{3}$, further supporting a hypothesis of fast denitrification relative to the scales of observation.

These patterns of $\mathrm{O}_{2}$ and $\mathrm{NO}_{3}$ occurrence indicate that aquifer-scale $\mathrm{NO}_{3}$ reactivity in the La Pine aquifer can be conceptualized with a redox boundary mapped on the basis of presence or absence of redox indicator species such as $\mathrm{O}_{2}$. An oxic/suboxic boundary for the La Pine aquifer was delineated (Fig. 10) by constraining the elevation of the oxic/suboxic boundary at each project well and then contouring these elevations in a manner similar to that required to map a subsurface lithologic contact from well logs. Such a redox boundary could be used for conceptualizing $\mathrm{NO}_{3}$ reactivity for regional vulnerability assessments or could be used as a reaction boundary for an aquifer-scale $\mathrm{NO}_{3}$ transport model.

The use of a redox boundary to conceptualize or represent $\mathrm{NO}_{3}$ reactivity has limitations. Denitrification at microsites of anoxia within the oxic zone of the aquifer will not be accounted for with such a conceptualization; in transport simulations, this could lead to a positive bias in $\mathrm{NO}_{3}$ concentrations in the oxic zone. Also, a redox boundary approach 


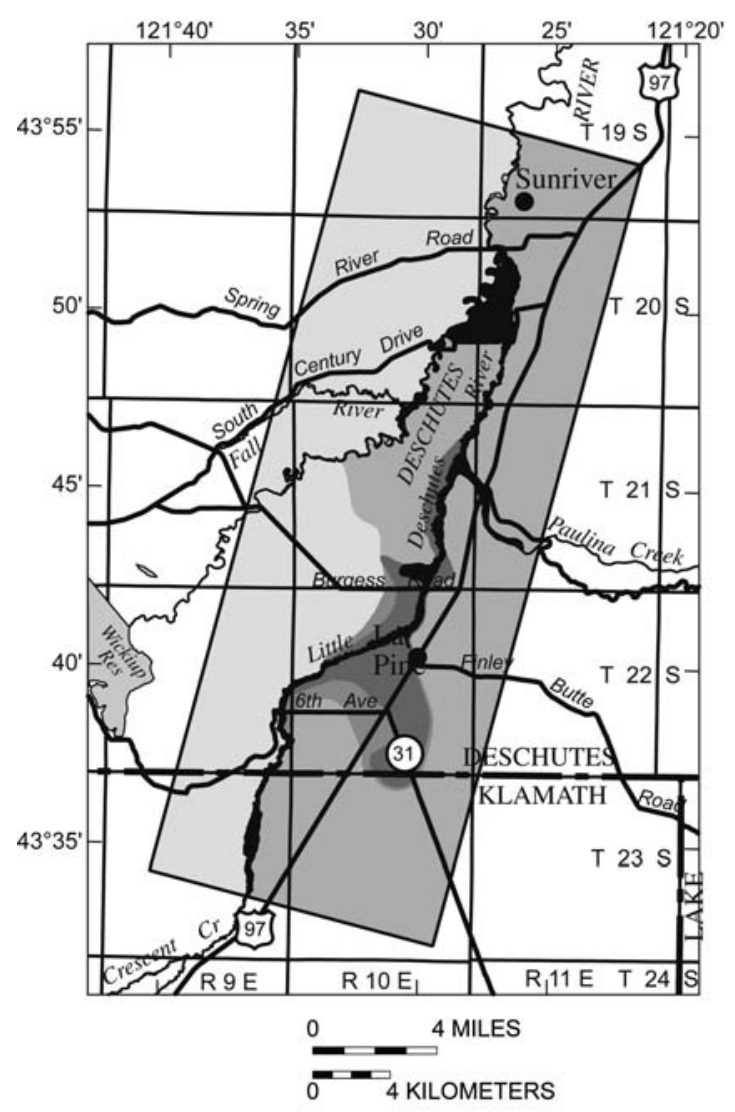

EXPLANATION

Estimated thickness of the oxic saturated zoneOxic ground water is defined to be water with a dissolved oxygen concentration $>$ or $=0.5 \mathrm{mg} / \mathrm{L}$.

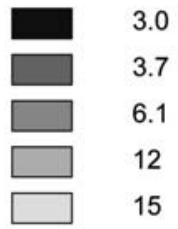

Base modified from U.S. Geological Survey 1:500,000 state base map, 1982 with digital data from U.S. Bureau of the Census, TIGER/Line (R), 1990 and U.S. Geological Survey Digital Line Graphs published at 1:100,000

Publication projection is Lambert Conformal Conic

Standard parallels $42^{\circ} 20^{\prime}$ and $44^{\circ} 40^{\prime}$, central meridian $-120^{\circ} 30^{\circ}$ Datum is NAD83

Figure 10 Map showing the estimated oxic saturated zone thickness (depth from top of water table to oxic/suboxic boundary), derived from contouring data from 256 wells.

will not account for $\mathrm{NO}_{3}$ that remains after $\mathrm{O}_{2}$ has been consumed - usually $\mathrm{NO}_{3}$ will continue to be advected for some discrete distance beyond the oxic/suboxic boundary. The combined effect of these two limitations in a redox-boundary transport simulation will be to misrepresent what may be a gradational $\mathrm{NO}_{3}$ front as a sharp (presence/absence) front. Another limitation of a redox boundary conceptualization is that such a boundary will migrate as solid-phase electron donors are consumed by $\mathrm{O}_{2}$ and $\mathrm{NO}_{3}$ reduction. Nevertheless, the effectiveness of a redox boundary for characterizing zones of current $\mathrm{NO}_{3}$ stability and instability in the La Pine aquifer is supported by analysis of ODEQ synoptic data. Of the ODEQ synoptic wells for which well con- struction data were available and for which $\mathrm{NO}_{3}$ concentrations were $>1 \mathrm{mg} / \mathrm{L} \mathrm{NO}_{3}-\mathrm{N}$ (37 wells), 35 were screened at least in part in the mapped (Fig. 10) oxic zone. Thus, the field data indicate that, on the temporal and spatial scales of ground-water flow in the La Pine aquifer, the redox boundary may give a better representation of $\mathrm{NO}_{3}$ transport than a uniform kinetic reaction model because the redox boundary appears to be controlled by a heterogeneous distribution of electron donors.

\section{Summary}

Septic tank effluent is the primary anthropogenic source of $\mathrm{NO}_{3}$ to the La Pine aquifer. In contrast, elevated concentrations of $\mathrm{NH}_{4}$ in the aquifer appear to originate from a natural source, probably sedimentary organic matter. A septic tank source of $\mathrm{NO}_{3}$ and $\mathrm{Cl}$ is evident in $\mathrm{NO}_{3} / \mathrm{Cl}$ relations, demonstrating mixing of septic-tank-derived $\mathrm{NO}_{3}$ and $\mathrm{Cl}$ with a dilute precipitation end-member. Association of $\mathrm{NH}_{4}$ with low- $\mathrm{Cl}$ ground water and correlation between total dissolved $\mathrm{N}$ and $\mathrm{C}$ in ground water are consistent with an organic matter source for the $\mathrm{NH}_{4} . \delta^{15} \mathrm{~N}$ values in $\mathrm{NO}_{3}$ were generally higher than $\delta^{15} \mathrm{~N}$ values in the $\mathrm{NH}_{4}$, supporting a septic tank source for the $\mathrm{NO}_{3}$ and a natural source for the $\mathrm{NH}_{4} \cdot \mathrm{NO}_{3}$ was found in modern $(<40 \mathrm{y})$, shallow ground water as isolated or coalescing plumes within several meters of the water table. $\mathrm{NH}_{4}$ generally occurred in old (pre-bomb) ground water, either in deep portions of the aquifer or in shallow ground water near discharge zones where regional ground water discharges to rivers. Thus, although septic tank $\mathrm{N}$ itself occurs as reduced $\mathrm{N}$, primarily as $\mathrm{NH}_{4}$, this reduced $\mathrm{N}$ is readily oxidized once it leaves the septic tank environment, and it does not represent an important source of $\mathrm{NH}_{4}$ in this aquifer system.

Denitrification in portions of the La Pine aquifer is indicated by decreases in $\mathrm{NO}_{3} / \mathrm{Cl}$ ratios in suboxic water relative to oxic water, the timing of $\mathrm{NO}_{3}$ loss relative to the progressive geochemical evolution towards increasingly reduced conditions, and the presence of elevated $\mathrm{N}_{2}$ / Ar ratios and $\delta^{15} \mathrm{~N}-\mathrm{N}_{2}$ values in some samples. An aquifer-scale oxic/ suboxic redox boundary successfully represents most instances of $\mathrm{NO}_{3}$ stability and instability, and thus serves as an effective means of conceptualizing the occurrence of denitrification at the aquifer scale.

\section{Acknowledgements}

This work was funded by the Oregon Department of Environmental Quality, US Geological Survey Federal Matching Funds, and the US Geological Survey National Research Program. Barbara Rich, Dan Haldeman, Todd Cleveland, and Jill Johnson (Deschutes County Environmental Health Division) provided valuable information and logistical assistance.

\section{Appendix A. Supplementary data}

Supplementary data associated with this article can be found, in the online version, at doi:10.1016/j.jhydrol. 2006.09.013. 


\section{References}

Alhajjar, B.J., Harkin, J.M., Chesters, G., 1989. Detergent formula and characteristics of wastewater in septic tanks. Journal of the Water Pollution Control Federation 61, 605-613.

Andrews, J.N., 1992. Mechanisms for noble gas dissolution by groundwaters. In: International Atomic Energy Agency (Ed.), Isotopes of Noble Gases as Tracers in Environmental Studies. International Atomic Energy Agency, Vienna, pp. 87-110.

Aravena, R., Robertson, W.D., 1998. Use of multiple isotope tracers to evaluate denitrification in ground water: Study of nitrate from a large-flux septic system plume. Ground Water 36, 975-982.

Bates, B.D., 2000. An evaluation of denitrification under fifty-six pressurized mound septic systems for several soil types in Wisconsin. M.S. Thesis, University of Wisconsin, Stevens Point, Wisconsin, 204 pp.

Bauer, H.H., Vaccaro, J.J., 1987. Documentation of a deep percolation model for estimating ground-water recharge. US Geological Survey Open-File Report 86-536, 180 pp.

Böhlke, J.K., Coplen, T.B., 1995. Interlaboratory comparison of reference materials for nitrogen-isotope-ratio measurements. In: International Atomic Energy Agency (Ed.), Reference and Intercomparison Materials for Stable Isotopes of Light Elements. International Atomic Energy Agency Report IAEA-TECDOC-825, Vienna, pp. 51-66.

Böhlke, J.K., Denver, J.M., 1995. Combined use of groundwater dating, chemical, and isotopic analyses to resolve the history and fate of nitrate contamination in two agricultural watersheds, Atlantic coastal plain, Maryland. Water Resources Research 31, 2319-2339.

Böhlke, J.K., Gwinn, C.J., Coplen, T.B., 1993. New reference materials for nitrogen-isotope-ratio measurements. Geostandards Newsletter 17, 159-164.

Böhlke, J.K., Wanty, R., Tuttle, M., Delin, G., Landon, M., 2002. Denitrification in the recharge area and discharge area of a transient agricultural nitrate plume in a glacial outwash sand aquifer, Minnesota. Water Resources Research 38. doi:10.1029/ 2001 WR000663.

Böhlke, J.K., Smith, R.L., Miller, D.N., 2006. Ammonium transport and reaction in contaminated groundwater: Application of isotope tracers and isotope fractionation studies. Water Resources Research 42. doi:10.1029/2005WR004349.

Boyd, T.G., 1996. Groundwater recharge of the middle Deschutes Basin, Oregon. M.S. Thesis, Portland State University, Portland, Oregon, $86 \mathrm{pp}$.

Brenton, R.W., Arnett, T.L., 1993. Methods of analysis by the US Geological Survey National Water Quality Laboratory - determination of dissolved organic carbon by UV-promoted persulfate oxidation and infrared spectrometry. US Geological Survey Open-File Report 92-480, 12 pp.

Brock, T.D., Madigan, M.T., 1988. Biology of Microorganisms, fifth ed. Prentice-Hall, Englewood Cliffs, NJ, 835 pp..

Bunnell, J.F., Zampella, R.A., Morgan, M.D., Gray, D.M., 1999. A comparison of nitrogen removal by subsurface pressure dosing and standard septic systems in sandy soils. Journal of Environmental Management 56, 209-219.

Busenberg, E., Plummer, L.N., 1992. Use of chlorofluorocarbons $\left(\mathrm{CCl}_{3} \mathrm{~F}\right.$ and $\left.\mathrm{CCl}_{2} \mathrm{~F}_{2}\right)$ as hydrologic tracers and age-dating tools: The alluvium and terrace system of central Oklahoma. Water Resources Research 28, 2257-2283.

Busenberg, E., Plummer, L.N., Bartholomay, R.C., Wayland, J.E., 1998. Chlorofluorocarbons, sulfur hexafluoride, and dissolved permanent gases in ground water from selected sites in and near the Idaho National Engineering and Environmental Laboratory, Idaho, 1994-97. US Geological Survey Open-File Report 98-274, $72 \mathrm{pp}$.
Bushman, J.L., 1996. Transport and transformations of nitrogen compounds in effluent from sand filter-septic system draintile fields. M.S. Thesis, Oregon State University, Corvallis, Oregon, $78 \mathrm{pp}$.

Century West Engineering Corporation, 1982. La Pine Aquifer Management Plan. Bend, Oregon, variously paged.

Clesceri, L.S., Greenberg, A.E., Eaton, A.D., 1998. Standard Methods for the Examination of Water and Wastewater, 20th ed. American Public Health Association, Washington, DC, variously paged.

Connor, B.F., Currier, J.P., Woodworth, M.T., 2001. Results of the US Geological Survey's analytical evaluation program for standard reference samples distributed in October 2000. US Geological Survey Open-File Report 01-137, 116 pp.

Cook, P.G., Böhlke, J.K., 2000. Determining timescales for groundwater flow and solute transport. In: Cook, P.G., Herczeg, A.L. (Eds.), Environmental Tracers in Subsurface Hydrology. Kluwer, Boston, pp. 1-30.

Cook, P.G., Solomon, D.K., 1997. Recent advances in dating young groundwater: chlorofluorocarbons, ${ }^{3} \mathrm{H} /{ }^{3} \mathrm{He}$ and ${ }^{85} \mathrm{~K}$. Journal of Hydrology 191, 245-265.

Coplen, T.B., 1993. Uses of environmental isotopes. In: Alley, W.M. (Ed.), Regional Ground-Water Quality. Van Nostrand Reinhold, New York, pp. 227-254.

Farrar, J.W., Copen, A.M., 2000. Results of the US Geological Survey's analytical evaluation program for standard reference samples distributed in March 2000. US Geological Survey OpenFile Report 00-398, 107 pp.

Fishman, M.J. (Ed.), 1993. Methods of analysis by the US Geological Survey National Water Quality Laboratory - determination of inorganic and organic constituents in water and fluvial sediments. US Geological Survey Open-File Report 93-125, 217 pp.

Fishman, M.J., Friedman, L.C., 1989. Methods for determination of inorganic substances in water and fluvial sediments. US Geological Survey Techniques of Water-Resources Investigations, Book 5, Chapter A1, 545 pp.

Fogg, G.E., Rolston, D.E., Decker, D.L., Louie, D.T., Grismer, M.E., 1998. Spatial variation in nitrogen isotope values beneath nitrate contamination sources. Ground Water 36, 418-426.

Freeze, R.A., Cherry, J.A., 1979. Groundwater. Prentice-Hall, Englewood Cliffs, New Jersey, 604 pp..

Gannett, M.W., Lite, K.E., Jr., Morgan, D.S., Collins, C.A., 2001. Ground-water hydrology of the Upper Deschutes Basin, Oregon. US Geological Survey Water-Resources Investigations Report 004162, $77 \mathrm{pp}$.

Heaton, T.H.E., Vogel, J.C., 1981. Excess air in groundwater. Journal of Hydrology 50, 201-216.

Helsel, D.R., Hirsch, R.M., 1992. Statistical Methods in Water Resources. Elsevier, Amsterdam, 522 pp..

Hinkle, S.R., Weick, R.J., Johnson, J.M., Cahill, J.D., Smith, S.G., Rich, B.J., 2005. Organic wastewater compounds, pharmaceuticals, and coliphage in ground water receiving discharge from onsite wastewater treatment systems near La Pine, Oregon: occurrence and implications for transport. US Geological Survey Scientific Investigations Report 2005-5055, 98 pp.

Högberg, P., 1997. Tansley Review No. $95{ }^{15} \mathrm{~N}$ natural abundance in soil-plant systems. New Phytologist 137, 179-203.

Howarth, R.W., Marino, R., 2006. Nitrogen as the limiting nutrient for eutrophication in coastal marine ecosystems: Evolving views over three decades. Limnology and Oceanography 51, 364-376.

Hübner, H., 1986. Isotope effects of nitrogen in the soil and biosphere. In: Fritz, P., Fontes, J.Ch. (Eds.), Handbook of Environmental Isotope Geochemistry, vol. 2. Elsevier, New York, pp. 361-425.

Kendall, C., Aravena, R., 2000. Nitrate isotopes in groundwater systems. In: Cook, P.G., Herczeg, A.L. (Eds.), Environmental Tracers in Subsurface Hydrology. Kluwer, Boston, pp. 261-297. 
Kinzelbach, W., Schafer, W., Herzer, J., 1991. Numerical modeling of natural and enhanced denitrification processes in aquifers. Water Resources Research 27, 1123-1135.

Klots, C.E., Benson, B.B., 1963. Isotope effect in the solution of oxygen and nitrogen in distilled water. Journal of Chemical Physics 38, 890-892.

Kölle, W., Strebel, O., Böttcher, J., 1985. Formation of sulfate by microbial denitrification in a reducing aquifer. Water Supply 3 , 35-40.

Lite, K.E., Jr., Gannett, M.W., 2002. Geologic framework of the regional ground-water flow system in the upper Deschutes Basin, Oregon. US Geological Survey Water-Resources Investigations Report 02-4015, 44 pp.

MacQuarrie, K.T.B., Sudicky, E.A., Robertson, W.D., 2001. Multicomponent simulation of wastewater-derived nitrogen and carbon in shallow unconfined aquifers II. Model application to a field site. Journal of Contaminant Hydrology 47, 85-104.

McMahon, P.B., Böhlke, J.K., Bruce, B.W., 1999. Denitrification in marine shales in northeastern Colorado. Water Resources Research 35, 1629-1642.

Morgan, D.S., Hinkle, S.R., Weick, R.J., 2002. Simulation of flow and transport of septic-derived nitrate at multiple scales within a heterogeneous alluvial aquifer system. Abstract. Eos, Transactions of the American Geophysical Union, 83, fall meeting supplement.

National Atmospheric Deposition Program, no date. Statistical summary of precipitation chemistry for valid samples. Retrieved April 27, 2005 from <http://nadp.sws.uiuc.edu/ nadpdata/>.

National Climatic Data Center, 2005a. Bend, Oregon NCDC 19611990 Monthly Normals. Retrieved April 27, 2005 from <http:// www.wrcc.dri.edu/cgi-bin/cliMAIN.pl?orbend>.

National Climatic Data Center, 2005b. Wickiup Dam, Oregon NCDC 1961-1990 Monthly Normals. Retrieved April 27, 2005 from <http://www.wrcc.dri.edu/cgi-bin/cliMAIN.pl?orwick>.

Oregon Department of Environmental Quality, 1982. Oregon On-Site Experimental Systems Program. Portland, Oregon, variously paged.

Oregon Department of Environmental Quality, 1994. Statewide Groundwater Monitoring Program, Lapine Area Groundwater Investigation, Deschutes County, Oregon, v. II. Portland, Oregon, variously paged.

Östlund, H.G., Dorsey, H.G., Rooth, C.G., 1974. GEOSECS North Atlantic radiocarbon and tritium results. Earth and Planetary Science Letters 23, 69-86.

Patton, C.J., Truitt, E.P., 1992. Methods of analysis by the US Geological Survey National Water Quality Laboratory determination of total phosphorus by a Kjeldahl digestion method and an automated colorimetric finish that includes dialysis. US Geological Survey Open-File Report 92-146, 39 pp.

Patton, C.J., Truitt, E.P., 2000. Methods of analysis by the US Geological Survey National Water Quality Laboratory - determination of ammonium plus organic nitrogen by a Kjeldahl digestion method and an automated photometric finish that includes digest cleanup by gas diffusion. US Geological Survey Open-File Report 00-170, $31 \mathrm{pp}$.

Plummer, L.N., Busenberg, E., 2000. Chlorofluorocarbons. In: Cook, P.G., Herczeg, A.L. (Eds.), Environmental Tracers in Subsurface Hydrology. Kluwer, Boston, pp. 441-478.

Plummer, L.N., Mullin, A.H., 1997a. Tritium/helium dating of ground-water samples available through contract with Lamont-Doherty Earth Observatory of Columbia University, Palisades, New York. US Geological Survey National Water Quality Laboratory Technical Memorandum 97.04 (available at <http://wwwnwql.cr.usgs.gov/Public/tech_memos/nwql. 97-04.html >).
Plummer, L.N., Mullin, A.H., 1997b. Collection, processing, and analysis of ground-water samples for tritium/helium-3 dating. US Geological Survey National Water Quality Laboratory Technical Memorandum 97.04S (available at <http://wwwnwql. cr.usgs.gov/Public/tech_memos/sup_nwql.97-04S.html>).

Postma, D., Boesen, C., Kristiansen, H., Larsen, F., 1991. Nitrate reduction in an unconfined sandy aquifer: Water chemistry, reduction processes, and geochemical modeling. Water Resources Research 27, 2027-2045.

Puckett, L.J., Cowdery, T.K., McMahon, P.B., Tornes, L.H., Stoner, J.D., 2002. Using chemical, hydrologic, and age dating analysis to delineate redox processes and flow paths in the riparian zone of a glacial outwash aquifer-stream system. Water Resources Research 38. doi:10.1029/2001WR000396.

Rich, B.J., 2001. Oregon Department of Environmental Quality, written communication.

Robertson, W.D., Cherry, J.A., 1992. Hydrogeology of an unconfined sand aquifer and its effect on the behavior of nitrogen from a large-flux septic system. Applied Hydrogeology 1, 3244.

Robertson, W.D., Russell, B.M., Cherry, J.A., 1996. Attenuation of nitrate in aquitard sediments of southern Ontario. Journal of Hydrology 180, 267-281.

Schlosser, P., Stute, M., Sonntag, C., Münnich, K.O., 1989. Tritiogenic ${ }^{3} \mathrm{He}$ in shallow groundwater. Earth and Planetary Science Letters 94, 245-256.

Solomon, D.K., Cook, P.G., 2000. ${ }^{3} \mathrm{H}$ and ${ }^{3} \mathrm{He}$. In: Cook, P.G., Herczeg, A.L. (Eds.), Environmental Tracers in Subsurface Hydrology. Kluwer, Boston, pp. 397-424.

Spalding, R.F., Exner, M.E., 1993. Occurrence of nitrate in groundwater - a review. Journal of Environmental Quality 22, 392402.

Straub, K.L., Benz, M., Schink, B., Widdel, F., 1996. Anaerobic, nitrate-dependent microbial oxidation of ferrous iron. Applied and Environmental Microbiology 62, 1458-1460.

Stute, M., Schlosser, P., 2000. Atmospheric noble gases. In: Cook, P.G., Herczeg, A.L. (Eds.), Environmental Tracers in Subsurface Hydrology. Kluwer, Boston, pp. 349-377.

Taylor, G.H., 1993. Normal annual precipitation, State of Oregon. Oregon Climate Service, Oregon State University, Corvallis, map.

Tesoriero, A.J., Liebscher, H., Cox, S.E., 2000. Mechanism and rate of denitrification in an agricultural watershed: Electron and mass balance along groundwater flow paths. Water Resources Research 36, 1545-1559.

US Committee on Extension to the Standard Atmosphere, 1976. US Standard Atmosphere, 1976. US Government Printing Office, Washington, DC, 227 pp.

US Environmental Protection Agency, 1978. Management of small waste flows. US Environmental Protection Agency report EPA600/2-78-173, Cincinnati, Ohio, variously paged.

US Geological Survey, 1999. National field manual for the collection of water-quality data. US Geological Survey Techniques of Water-Resources Investigations, book 9, Chapters A1-A9, variously paged (available at <http://pubs.water.usgs.gov/ twri9A>).

Vogel, J.C., 1967. Investigation of groundwater flow with radiocarbon. In: International Atomic Energy Agency (Ed.), Isotopes in Hydrology. IAEA, Vienna, pp. 355-369.

Walker, W.G., Bouma, J., Keeney, D.R., Magdoff, F.R., 1973. Nitrogen transformations during subsurface disposal of septic tank effluent in sands: I. Soil transformations. Journal of Environmental Quality 2, 475-480.

Weiss, R.F., 1970. The solubility of nitrogen, oxygen, and argon in water and seawater. Deep-Sea Research 17, 721-735.

Weiss, R.F., 1971. Solubility of helium and neon in water and seawater. Journal of Chemical and Engineering Data 16, 235241. 
Wilhelm, S.R., Schiff, S.L., Cherry, J.A., 1994. Biogeochemical evolution of domestic waste water in septic systems: 1. Conceptual model. Ground Water 32, 905-916.

Wilhelm, S.R., Schiff, S.L., Robertson, W.D., 1996. Biogeochemical evolution of domestic waste water in septic systems: 2 .
Application of conceptual model in sandy aquifers. Ground Water 34, 853-864.

World Health Organization, 1996. Guidelines for Drinking-Water Quality, vol. 2, Health Criteria and Other Supporting Information, second ed. World Health Organization, Geneva, 973 pp. 